International Journal of

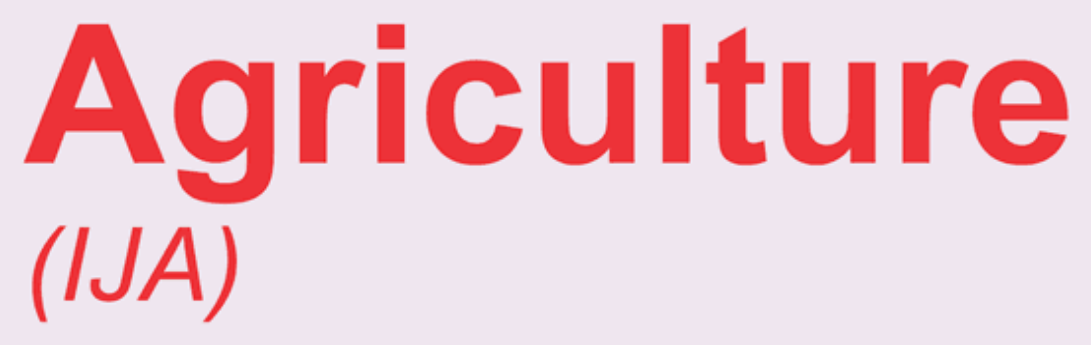

\title{
ASSESSMENT OF PHOSPHORUS AVAILABILITY FROM UNREACTIVE TOGO PHOSPHATE ROCK BY LEGUME AND CEREAL CROPS IN TWO GHANAIAN SOILS
}

Alex Boateng and Prof. Emmanuel Owusu-Bennoah

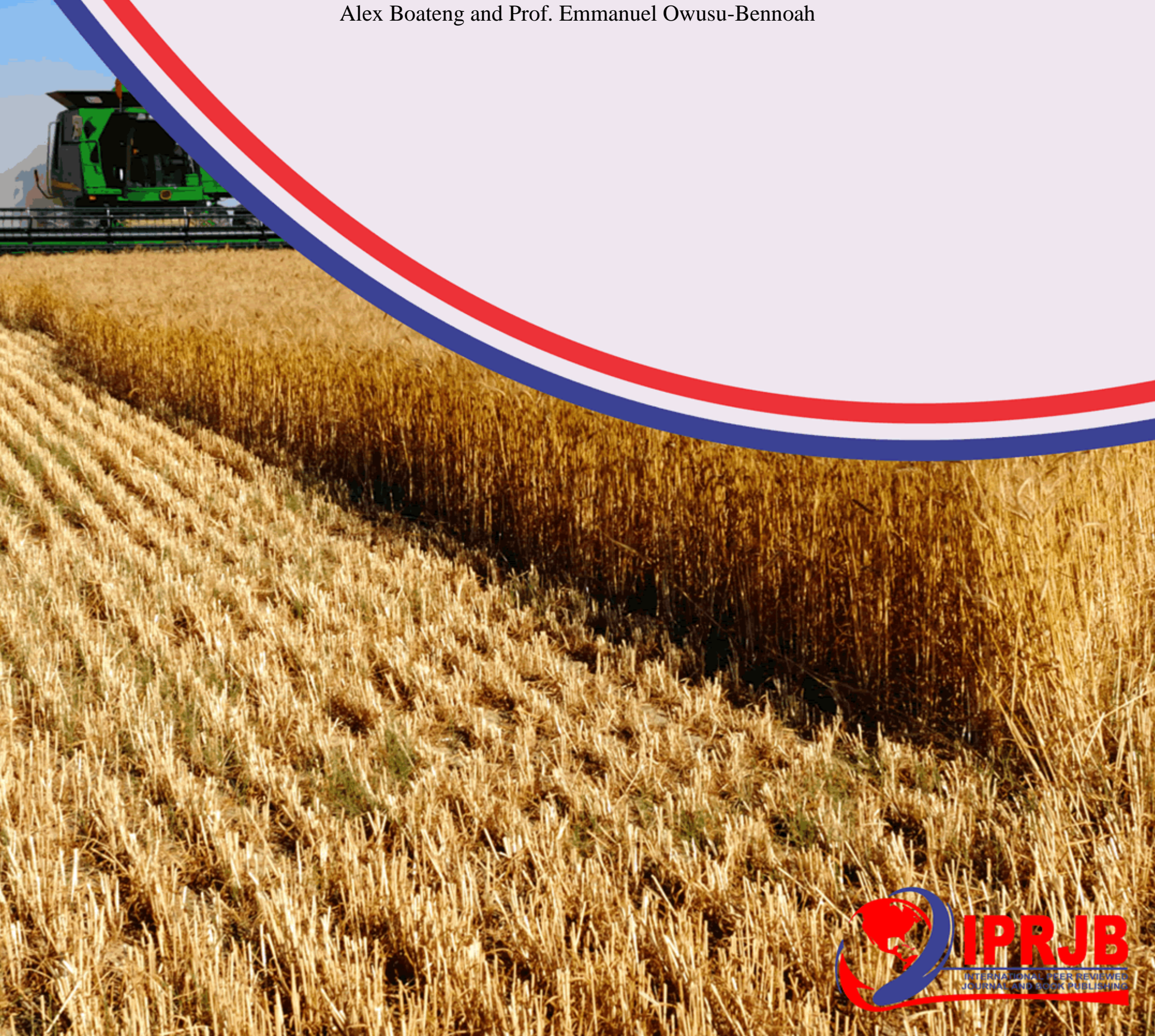




\title{
ASSESSMENT OF PHOSPHORUS AVAILABILITY FROM UNREACTIVE TOGO PHOSPHATE ROCK BY LEGUME AND CEREAL CROPS IN TWO GHANAIAN SOILS
}

\author{
$1^{*}$ Alex Boateng \\ Mount Mary College of Education \\ Corresponding Author Email: kabtsara@gmail.com \\ ${ }^{2}$ Prof. Emmanuel Owusu-Bennoah \\ Lecturer, Soil Science Department: University of Ghana
}

\begin{abstract}
Purpose: In recent years, phosphate rock (PR) for direct application has been tested in tropical acid soils as a potential alternative to conventional water-soluble $\mathrm{P}$ fertilizers like Single Superphosphate (SSP) and Triple Superphosphate (TSP). However, direct application of PR with low reactivity does not always give satisfactory results. Legume and cereal crops represent a strategy that can be used to solubilize P from some of these unreactive PRs. The objective of this study was to assess the availability of $\mathrm{P}$ from unreactive Togo Phosphate Rock (TPR) relative to TSP by six (6) crop species in two Ghanaian soils.
\end{abstract}

Methodology: The study was conducted in the greenhouse of the Crop Science Department, University of Ghana. Three P rates, $0 \mathrm{mg}$, 50mg and 100mg P of TPR and TSP were applied to a kilogram of soil per pot in the two soil series. Randomized Complete Block Design was used to do the analyses.

Results/Findings: Application of TSP resulted in higher dry matter and P uptake irrespective of the soil type. Among the legumes, cowpea gave the highest dry matter yield. Fairly, a similar trend was obtained with the application of TPR. Among the cereals, the average P uptake by sorghum from TPR was the highest, followed by maize and millet in the Nzema soil. In the Adenta series, $\mathrm{P}$ uptake by maize was the highest, followed by sorghum and millet. Phosphorus (P) uptake by the cereals from TPR was generally better in the Adenta than the Nzema soil.

Unique contribution to theories, practice and policy: Results show increasing the rate of TPR to $100 \mathrm{mg} \mathrm{P} /$ pot resulted in an increase in dry matter yield and $\mathrm{P}$ uptake in both soils, but was inferior to $100 \mathrm{mg}$ P/pot TSP application. Consequently, the rate of application of TPR should always be high if farmers want the best from their investments. Again, the low relative agronomic effectiveness of TPR for all the crops, proved the low reactivity of the material and its subsequent low performance compared with the water-soluble $\mathrm{P}$. The low reactivity and the high molar mass of $\mathrm{PO}_{4}{ }^{3-} / \mathrm{CO}_{3}{ }^{2-}$ of the TPR will always make it difficult for $\mathrm{P}$ to be made available from the TPR despite the acidity of the soil, the high density of the crops and the ability of the tested crops to exude organic acids, which facilitate phosphorus availability from TPR, therefore making TPR unsuitable for direct application.

Key words: Phosphate rock, Adenta, Nzema, Paleustalf, Relative Agronomic Effectiveness, Organic acids 


\subsection{INTRODUCTION}

One of the major problems that have constrained the development of an economically successful, sustainable agriculture in in the whole world, particularly the Sub-Saharan Africa (SSA) is a prevalent poor soil fertility for crop production. Many of the agricultural soils in the tropical and subtropical regions are low in both total and available phosphorus $(\mathrm{P})$, which is an essential plant nutrient (Bationo et al., 1998; Vanlauwe et al., 2002). Phosphorus is critically needed to improve soil fertility for crop production in large areas of developing countries due to phosphorus fixation by $\mathrm{Fe}$ and $\mathrm{Al}$ oxides (Sample et al., 1980). Manufactured water-soluble phosphorus (WSP) fertilizers such as superphosphates are commonly recommended for correcting $\mathrm{P}$ deficiencies. However, most developing countries, including Ghana, import these fertilizers, which are often in limited supply and represent a major capital outlay for resource-poor farmers (OwusuBennoah et al., 2000). Thus, finding economical material to overcome phosphorus deficiency is an integral part of any solution to the problems of agricultural development in most developing countries of SSA.

Due to the low income of Ghanaian farmers, there is an increasing interest in the use of cheaper alternative phosphorus fertilizers such as indigenous phosphate rock for direct application. The direct application of phosphate rock is an agronomic and economically sound alternative to the more expensive superphosphates in the tropics (Diata, 2014; Chien \& Hammond, 1978; Truong et al., 1978; Zapata et al., 1986; Hammond et al., 1986b; Chien and Hammond, 1989; Chien et al., 1990a; Bationo \& Mokwunye, 1991; World Bank, 1992; Gerner \& Baanante, 1995; Kuyvenhoven \& Lanser, 1999; Sale \& Mokwunye, 1993). The major constraint on the application of PRs however, is the low reactivity of the many locally available PR sources. According to Chien and Hammond (1978), the effectiveness of local phosphate rock depends on its chemical and mineralogical composition. To increase PR solubility for direct application, biological, physical, and chemical methods have been employed.

For example, Phosphate-Solubilizing Bacteria (PSB) have been known to have the ability to solubilize PR effectively so that its performance can equate that of triple superphosphate (TSP) (Amankwa, 2010). The challenge with this method, however, is that using PSB on acid soils will not yield the needed results for legumes since the rhizobia cannot grow effectively and poor nodulation and low N have been recorded (Dakora \& Philip, 2002; Giller, 2001; Hungaria \& Vergas, 2000; Danso, 1977). Most workers have also recommended organic amendments as the best alternative (Singh \& Amberger, 1990; Akande et al 1998, 2005) but sources of these organic materials are severely restricted and where available tend to be very bulky and expensive to transport. Partially acidulating rock phosphate has also been said to be as effective as SSP or TSP (Sahrawat et al., 2001) but acidulation also has its consequential effects of polluting water, soil and the environment.

Several studies have shown that legumes are particularly suited for the use of PRs (Ankomah et al., 1995; Kamh et al., 1999 Randhawa 2003). They are effective in dissolving PR and in absorbing its dissolution products because of their demand for $\mathrm{Ca}$ and the acidifying effect of nitrogen $(\mathrm{N})$ fixation in the soil near the root system (rhizosphere) (Ankomah et al., 1995; Kamh et al., 1999; Randhawa 2003). This effect of using legumes with PRs can be utilized to improve the $\mathrm{P}$ nutrition of a companion crop (intercropping) or that of the subsequent crop in a rotation 
(Horst \& Waschkies, 1987; Vanlauwe et al., 2000). Some plant species, for example, rapeseed, lupines and pigeon pea have been studied for their ability to secrete organic acids that result in an enhanced dissolution of PR (Jones, 1998; Hoffland, 1992; Adams \& Pate, 1992; Ae et al., 1990; Montenegro \& Zapata, 2002). Recent studies by Chien (2003) indicated that reactive PRs may have potential applications, even in alkaline soils with organic-acid secreting crops such as rapeseed. Hinsinger \& Gilkes (1995) and Habib et al., (1999) have also found enhanced PR dissolution in the rhizosphere of some crop species in alkaline soils. If legumes can enhance PR dissolution, then there is an opportunity to use them for increasing the agronomic effectiveness of PR.

Cereals constitute a major staple food crop in SSA. They are grown extensively by the smallholder farmers and serve as a source of energy for the local farmers and the entire farming community. It has been shown that cereal growth is dependent on availability of $\mathrm{P}$ in the soil, but soils in SSA have low available P. Flach et al (1987) demonstrated that some cereal crop species have the mobilizing capacity to solubilize P from PRs. Petersen and Bottger (1991) have also shown that cereals, especially maize, were able to solubilize P from PR by excreting organic acids. Campaore et al. (2011) have also shown that maize was able to solubilize P from Burkina Kodjare phosphate rock while on the contrary; Chien et al. (1995) have shown that the RAE of PR for crops with lower P demands, such as legume crops is higher than for cereal crops such as maize.

The direct application of ground, natural PR as a source of $\mathrm{P}$ for crops is a practice that has been utilized with varying degrees of popularity over the years. Numerous field and greenhouse experiments have been conducted during the past 100 years or more to assess the capabilities of these materials to supply $\mathrm{P}$ to crops and to define the most favourable conditions for their application. The results obtained have been reported as erratic and sometimes conflicting, leading to confusion and disagreement on the utilization of PRs (Khasawneh and Doll, 1978).

As interest in the use of PRs for crop production in the whole world increases, especially South Saharan Africa, more research is needed to compare the Relative Agronomic Effectiveness of local deposits of PRs such as Togo Rock Phosphate, as influenced by local crop species because of conflicting reports over the years regarding utilization of PR, therefore it is imperative to conduct this research so that screening of these local crops with respect to their ability to utilize phosphorus from sparingly soluble PRs from the region will enhance the selection of appropriate crop combinations for cereal-based cropping systems, optimizing crop production and economic benefit. Though the many countries seem to do more in the area of direct application of phosphate rock, Ghana in particular, has done little and it is about time more researches are carried out in this field so as to boost the production of the small holder farmers in the country, hence this research.

The hypothesis of this study is that the RAE of unreactive Togo PR would be higher for crops with lower $\mathrm{P}$ demand such as legume crops than cereal crops.

The objective of the study, therefore was to assess $\mathrm{P}$ availability from unreactive Togo PR by legumes (cowpea, soybean, pigeon pea) and cereals (maize, millet, sorghum) in two Ghanaian soils due It is hoped that the findings of this study will help improve legume/cereal cropping 
International Journal of Agriculture

ISSN 2520-4629X (Online)

Vol.5, Issue 1, pp 1 - 24, 2020

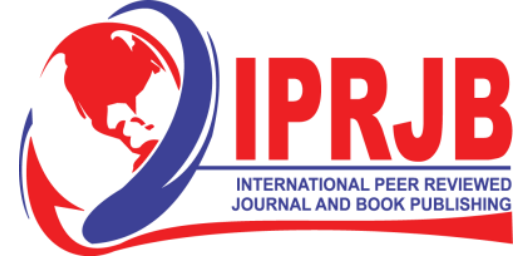

www.iprjb.org

systems of farmers in the region by using sparingly PR as against the more expensive WSP fertilizers and thereby halting the declining per capita food production in SSA.

\subsection{MATERIALS AND METHODS}

\section{Soils and sampling}

Five representative surface samples from the plough layer $(0-15 \mathrm{~cm})$ of each of two the soil series, Adenta and Nzema, representing the Coastal savanna and Forest zones of Ghana, were taken. The samples were air-dried, crushed and passed through a $2 \mathrm{~mm}$ sieve to obtain the fine earth fraction.

\section{Adenta series}

The Adenta series has been classified as Paleustalf and Hypedystric Acrisol according to USDA $(1999,2003)$ and ISSS-ISRIC-FAO (WRB) (1998) respectively, and it occupies the middle slope position on the landscape of the Legon hill in the Greater Accra of Ghana. It is a well-drained soil. Baah (2010) also classified it as Paleustalf and it is acidic with $\mathrm{pH}$ of 5.8 in the surface horizon but increases in acidity with depth. The mean annual temperature and rainfall is $27^{\circ} \mathrm{C}$ and $800 \mathrm{~mm}$ respectively

\section{Nzema series}

The Nzema series (Ultisol), described as Paleustalf (USDA 1999), was sampled from the Agricultural Research Station, Kade (6043 N: 1036 W) in the Eastern Region of Ghana. It also occupies the middle slope position of the catena with mean annual rainfall ranging from 1500 to $2000 \mathrm{~mm}$. It is found in a semi-deciduous rainforest and it is acidic with a pH ranging from 4.95.2. It is a moderately-well drained soil.

\section{Soil physical analysis}

\section{Particle size analysis}

Particle size distribution was carried out by the Bouyoucos method (1962). Forty gram sample of a $2 \mathrm{~mm}$ sieved soil was weighed into a beaker and $100 \mathrm{ml}$ of $5 \%$ calgon (sodium hexametaphosphate) solution was added. The suspension was shaken on a mechanical shaker for $2 \mathrm{~h}$. The suspension was thereafter transferred into a graduated sedimentation cylinder and distilled water added to bring the level to the 1 litre mark. A plunger was used to stir the suspension vigorously by moving the plunger in and out several times and the first and second hydrometer readings were taken at $5 \mathrm{~min}$ and $5 \mathrm{~h}$ from the time of mixing the suspension, representing silt + clay and clay respectively. The sand fraction was obtained by decanting the suspension from the sedimentation cylinder and recording the dried weight after it had been oven-dried for two (2) days and cooled in a desiccator. Blank hydrometer readings of sodium hexametaphosphate solution at $5 \mathrm{~min}$ and $5 \mathrm{~h}$ were taken.

The percentages of the various soil separates were then determined as follows:

a) Silt $(\%)+$ Clay $(\%)=$ Corrected hydrometer reading at $5 \mathrm{~min} \times 100 /$ sample weight $(\mathrm{g})$

b) Clay $(\%)=$ Corrected hydrometer reading at $5 \mathrm{~h} \mathrm{x} 100 /$ sample weight $(\mathrm{g})$

c) Silt $(\%)=a-b$ 


\section{d) Sand $(\%)=100-\mathrm{a}$}

The texture of the soil was determined using the USDA textural triangle.

\section{Field Capacity Determination}

One (1) $\mathrm{kg}$ of each of the soils was weighed in triplicate and was saturated with water and allowed to drain in plastic pots for two days in an open air. Sub samples were taken from the wet soil and oven-dried at a temperature of $105^{\circ} \mathrm{C}$ for $24 \mathrm{~h}$ to constant weight and final weight recorded. The difference between the moist weight and the dry weight was taken as the mass of the water at field capacity.

$\%$ Water content at field capacity $=\underline{(\text { Weight of moist soil })-(\text { Weight of oven-dried soil }) \times 100}$

(Weight of oven-dried soil)

\section{Soil Chemical Analysis}

\section{Soil pH}

Soil $\mathrm{pH}$ was determined in both distilled water and $0.01 \mathrm{M}$ calcium chloride using a MV 88 Pracitronic $\mathrm{pH}$ glass electrometer. Ten grams $(10 \mathrm{~g})$ of the soil sample were weighed into a $50 \mathrm{ml}$ beaker and $10 \mathrm{ml}$ of distilled water was added. The soil-liquid suspension was then stirred several times for $30 \mathrm{~min}$ and allowed to stand for most of the suspended clay to settle out. Using buffer solutions of $\mathrm{pH} 4.0$ and 7.0, the $\mathrm{pH}$ electrometer was standardized. The standardized electrode was then inserted into the supernatant of the suspension to measure the $\mathrm{pH}$ of the soil sample. The procedure was repeated with $20 \mathrm{~g}$ of soil and $40 \mathrm{ml}$ of $0.01 \mathrm{M} \mathrm{CaCl}_{2}$.

\section{Organic carbon}

The wet combustion method of Walkley and Black (1934) was used to determine the organic carbon contents of the soils. Ten millimeters of $0.167 \mathrm{M}$ potassium dichromate $\left(\mathrm{K}_{2} \mathrm{Cr}_{2} \mathrm{O}_{7}\right)$ solution and $20 \mathrm{ml}$ concentrated Sulphuric acid $\left(\mathrm{H}_{2} \mathrm{SO}_{4}\right)$ were added to $0.5 \mathrm{~g}$ soil (which had been passed through a $0.5 \mathrm{~mm}$ sieve) in an Erlenmeyer flask. The flask was then swirled to ensure full contact with the soil with the solution, after which it was allowed to stand for $30 \mathrm{~min}$. The unreduced $\mathrm{K}_{2} \mathrm{Cr}_{2} \mathrm{O}_{7}$ remaining in solution after the oxidation of the oxidizable organic material in the soil sample was titrated against $0.2 \mathrm{M}$ ferrous ammonium sulphate solution after adding $200 \mathrm{ml}$ of distilled water, $10 \mathrm{ml}$ of orthophosphoric acid and $2 \mathrm{ml}$ of barium diphenylamine sulphate indicator till colour changed from a brown colour to a bright green end point.

The percent organic carbon was calculated as:

$$
\% \mathrm{C}=\frac{0.3[10-(\mathrm{XN})] \times 1.33}{\mathrm{~W}}
$$

Where: $\mathrm{X}=\mathrm{ml}$ of $\mathrm{Fe}\left(\mathrm{NH}_{4}\right)_{2}\left(\mathrm{SO}_{4}\right)_{2}$ required for the titration

$\mathrm{N}=$ normality of $\mathrm{Fe}\left(\mathrm{NH}_{4}\right)_{2}\left(\mathrm{SO}_{4}\right)_{2}$

$\mathrm{W}=$ Weight of soil sample 
International Journal of Agriculture

ISSN 2520-4629X (Online)

Vol.5, Issue 1, pp 1 - 24, 2020

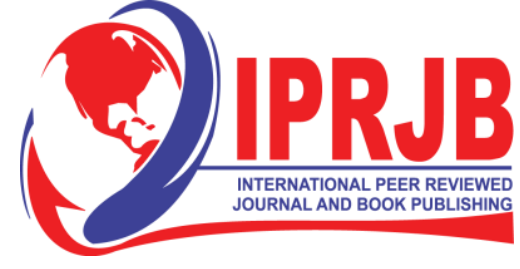

www.iprjb.org

\section{Available Phosphorus determination}

Available phosphorus was determined using Bray 1 method. Five grams $(5 \mathrm{~g})$ of soil was weighed into a centrifuge bottle and $50 \mathrm{ml}$ of Bray 1 solution $\left(0.03 \mathrm{~N} \mathrm{NH}_{4} \mathrm{~F}+0.025 \mathrm{~N} \mathrm{HCl}\right)$ was added. The suspension was shaken for about $5 \mathrm{~min}$ on a mechanical shaker and thereafter was made to stay overnight for the suspension to settle after which the suspension was filtered through a No. 42 Whatman filter paper into a $100 \mathrm{ml}$ volumetric flask and made up to the volume. Available phosphorus in the filtrate was determined using molybdate-ascorbic acid method of Watanabe and Olsen (1965) as follows:

Five (5) $\mathrm{ml}$ aliquots of the filtrate from the Adenta soil and $10 \mathrm{ml}$ aliquots of the filtrate from Nzema soil were taken into a $50 \mathrm{ml}$ volumetric flask in duplicates. The $\mathrm{pH}$ was adjusted using Pnitrophenol indicator and neutralized with a few drops of $4 \mathrm{M} \mathrm{NH}_{4} \mathrm{OH}$ until the solution turned yellow. The solutions were diluted to $40 \mathrm{ml}$ with distilled water after which $8 \mathrm{ml}$ of a mixture of $12 \mathrm{~g}$ ammonium molybdate, $0.29 \mathrm{~g}$ potassium antimony tartrate, $140 \mathrm{ml}$ concentrated $\mathrm{H}_{2} \mathrm{SO}_{4}$ and $1.056 \mathrm{~g}$ of ascorbic acid (reagent B) were added. The solutions were mixed thoroughly by shaking and allowing standing for $15 \mathrm{~min}$ for the colour to stabilize (The colour changed to blue of different shades depending on the concentration of the $\mathrm{P}$ in each sample. A blank was prepared with distilled water and $8 \mathrm{ml}$ of reagent $\mathrm{B}$. The spectrophotometer was calibrated using $25 \mathrm{mg} \mathrm{L}^{-1}$ standard $\mathrm{P}$ solution in the same manner as above. The intensity of the blue colour was measured using the Philips PU 8620 spectrophotometer at a wavelength of $712 \mathrm{~nm}$. The P concentration was read on the spectrophotometer and calculated as follows:

$$
\mathrm{P}\left(\mathrm{mg} \mathrm{kg}^{-1}\right) \text { soil }=\frac{(\text { Spectrophotometer reading-blank reading }) \mathrm{x} \text { volume of extract }}{\text { Volume of aliquot } \mathrm{x} \text { sample weight }(\mathrm{g})}
$$

\section{Total Phosphorus determination}

Total $\mathrm{P}$ was determined by digesting $2 \mathrm{~g}$ of $0.5 \mathrm{~mm}$ sized soil with $25 \mathrm{ml}$ of a mixture of concentrated $\mathrm{HNO}_{3}$ and $60 \% \mathrm{HCIO}_{4}$ in the ratio 2:3. The solution was heated on a digestion rack until the solution became colourless. The digest was cooled, diluted and filtered through a Whatman filter paper No. 42 into $250 \mathrm{ml}$ volumetric flask. The samples were analyzed for phosphorus using Murphy and Riley method (1962). The colour intensity was read using a spectrophotometer at a wavelength of $712 \mathrm{~nm}$.

$\mathrm{P}$ was calculated using the formula:

$\mathrm{P}(\mathrm{mg} / \mathrm{kg})=\underline{(\mathrm{Sp} . \text { Reading-Blank }) \times \text { Vol. of extract }}$

Vol. of aliquot $\mathrm{x}$ weight of soil

$\operatorname{RAE}(\%)=\underline{\text { Tested Phosphate Rock x } 100}$

Standard Fertilizer

\section{Exchangeable bases}

Ten grams of each soil sample was weighed into a $100 \mathrm{ml}$ centrifuge tube and $20 \mathrm{ml}$ of $1 \mathrm{M}$ $\mathrm{NH}_{4} \mathrm{OAc}$ at $\mathrm{pH} 7.0$ solution was added. The bottles with their contents were shaken for $1 \mathrm{~h}$, centrifuged at $1000 \mathrm{rpm}$ for $10 \mathrm{~min}$ and filtered through a Whatman No. 42 filter paper. The 
International Journal of Agriculture

ISSN 2520-4629X (Online)

Vol.5, Issue 1, pp 1 - 24, 2020

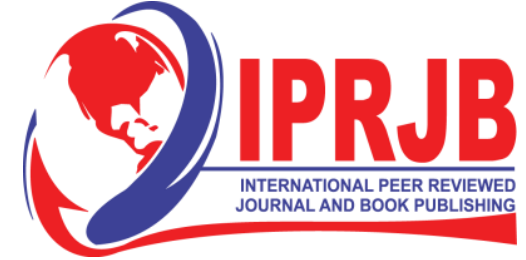

www.iprjb.org

ammonium saturated soil was washed three times with $95 \%$ ethanol by shaking for 15 min on a mechanical shaker and then centrifuged at $1000 \mathrm{rpm}$ for $10 \mathrm{~min}$. Calcium and magnesium in the extract were determined using Atomic Absorption Spectrometry. Potassium and sodium were determined by flame photometry.

$\% \mathrm{Ca}=($ AAS Reading/1000) $\times(100 / 1000) \times(100 / \mathrm{wt})$

$\mathrm{AAS}=$ atomic absorption spectrometry, to get $\mathrm{mg} / \mathrm{kg}$ multiply \%Ca by 10000

$\% \mathrm{~K}=($ ASS Reading $\mathrm{x}$ Extract $\mathrm{x} 100) / \mathrm{wt}$ of soil $\mathrm{x} 10^{6}$

Exchangeable acidity $\left(\mathrm{Al}^{3+}, \mathrm{H}^{+}\right)$and ECEC

Twenty-five $\mathrm{mL}$ of $1 \mathrm{M} \mathrm{KCl}$ was added to $10 \mathrm{~g}$ of soil sample in a $250 \mathrm{~mL}$ conical flask. The content was mixed by swirling and then allowed to stand for 30min. The suspension was filtered through a Whatman No. 42 filter paper into a volumetric flask. The soil was consecutively leached with five (5) batches of $25 \mathrm{ml} 1 \mathrm{M} \mathrm{KCl}$ to a total volume of about $150 \mathrm{ml}$. Four drops of phenolphthalein were added to the leachate and titrated against $0.1 \mathrm{M} \mathrm{NaOH}$ to the first permanent pink endpoint. Potassium chloride extractable exchangeable acidity was calculated as:

$\mathrm{C}$ mol kg ${ }^{-1} \mathrm{KCl}$ acidity $=(\mathrm{ml} \mathrm{NaOH}$ Sample- ml NaOH blank) $x \mathrm{M}$ x $100 /$ Sample $(\mathrm{g})$

Where, $\mathrm{M}$ is the molarity of $\mathrm{NaOH}$.

For estimation of $\mathrm{Al}^{3+}$ and $\mathrm{H}^{+}$, the titre for $\mathrm{NaOH}$ was recorded; $10 \mathrm{ml}$ of $1 \mathrm{M} \mathrm{NaF}$ was added to the $\mathrm{NaOH}$ and titrated with $0.1 \mathrm{M} \mathrm{HCl}$ until the pink colour disappeared. The solution was then allowed to stand for about $30 \mathrm{~min}$ and additional $\mathrm{HCl}$ added to a clear endpoint (Thomas, 1982). The effective cation exchange capacity (ECEC) was obtained by summation of the exchangeable bases and exchangeable acidity (Coleman et al., 1959). Percent Aluminium saturation was calculated as:

(Exchangeable Al) / ECEC * 100.

The green house set up, research design, population, sampling technique, data collection procedure and data analysis

\section{The Greenhouse Experiment}

Two soil series, Nzema and Adenta, were used for the experiment. Two hundred and sixteen plastic pots were arranged in greenhouse benches at the University of Ghana's greenhouse. Each of the pots was filled with a kilogram of soil each from one soil series (Adenta or Nzema) mixed with acid-washed sea sand. The sand was first washed continuously with tap water for 7 days, after which it was thoroughly washed again with distilled water to get rid of the sea water. The silver nitrate solution was used to check the level of saltiness in the sand intermittently. Concentrated Hydrochloric acid $(\mathrm{HCl})$ solution was poured onto the sand and was made to stand for 3 days to dissolve the $\mathrm{CaCO}_{3}$ concretions and other organic materials in the sand. The sand was further washed thoroughly with distilled water for four continuous/consecutive days to get rid of the $\mathrm{HCl}$ after which the sand was dried in the sun for 2 days. One $\mathrm{kg}$ of the soil and acidwashed sand were weighed in each of the $15.2-\mathrm{cm}$ diameter pots.

Two P sources, Togo PR and Triple superphosphate (TSP) were applied at rates of $0 \mathrm{mg} \mathrm{P} \mathrm{kg}^{-1}$, $50 \mathrm{mg} \mathrm{P} \mathrm{kg}^{-1}$, 100mg P kg${ }^{-1}$ soil equivalent to $0 \mathrm{~g}, 0.3125 \mathrm{~g}$ and $0.625 \mathrm{~g} \mathrm{PR}$ and $0 \mathrm{~g}, 0.25 \mathrm{~g}$ and $0.50 \mathrm{~g}$ 
TSP. The rates were based on the percent total $\mathrm{P}$ content in both sources. The total $\mathrm{P}$ content of the TSP is $20 \%$, while that of Togo PR is $16 \%$ (using $1 \%$ citric acid). Six test crops were used, namely; Soybean \{Glycine max-(TGX 1912-13F)\}, Cowpea \{Vigna unguiculata (Black eye)\}, Pigeon pea $\{$ Cajanus cajan $\}$, Sorghum $\{$ Sorghum bicolor--(Naga white) $\}$, Millet $\{$ Pennisetum typhoides-(Local millet) $\}$, and Maize $\{$ Zea mays L - (Obatanpa) $\}$. The treatments were replicated three times giving a total of 216 experimental units ( 6 crops x 2 sources of soil x 3 levels of $\mathrm{P} \times 2$ sources of $\mathrm{P} \times 3$ replications). The soil in each pot, except those for control treatments, was transferred to a bigger pot and a weighed amount of the $\mathrm{P}$ fertilizer was added, thoroughly mixed with the soil and returned to their respective pots.

The pots were laid out as a randomized complete block design with the pots re-randomized within each block and then rotated weekly to minimize uneven environmental effects within the greenhouse. Each pot received five seeds of the test crop and was thinned to two plants after emergence. Distilled water was added daily to maintain the soil at 45-60\% field capacity. Each pot containing a legume crop was supplied with the basal nitrogen application of $50 \mathrm{mg} \mathrm{N} \mathrm{kg}^{-1}$ equivalent to $0.1 \mathrm{~g}$ urea whilst each pot containing a cereal crop received the normal nitrogen recommendation of $100 \mathrm{mg} \mathrm{N} \mathrm{kg}^{-1}$ of urea. Potassium Sulphate was supplied to all pots at a rate of $150 \mathrm{mg} \mathrm{K} \mathrm{kg}^{-1}$. This application was done 7 days after seedlings had emerged. The plants were grown for 42 days, after which the tops of the crops were harvested. The crops were cut at the soil level and immediately the fresh weight of the shoot was taken. The harvested plants were thoroughly washed with distilled water to remove any soil particle on them. The washed plants were dried on a pad or tissue paper and placed in paper bags and dried in an oven at $70^{\circ} \mathrm{C}$ for 72 $\mathrm{h}$ to constant weight. Dry weights of the nodules were similarly taken. The dried plant materials were ground to pass through a $1 \mathrm{~mm}$ sieve after which they were stored for subsequent $\mathrm{N}, \mathrm{P}$ and $\mathrm{Ca}$ analysis.

\section{Digestion of plant material}

One-tenth gram $(0.1 \mathrm{~g})$ of the plant sample was weighed into a $25 \mathrm{ml}$ flask and $5 \mathrm{ml}$ of concentrated Sulphuric acid was added after which the flasks with its contents were each swirled intermittently to facilitate contact between the sample and the Sulphuric acid. The flask was allowed to stand overnight for the Sulphuric acid to dissolve the plant sample entirely. Thereafter, each solution was heated for some time after which Hydrogen Peroxide $\left(\mathrm{H}_{2} \mathrm{O}_{2}\right)$ was added until the solution became clear. Distilled water was added and the solutions were allowed to stand overnight to cool and settle after which they were decanted into $100 \mathrm{ml}$ flask. P in the digest was determined according to the method of Watanabe and Olsen (1965). Calcium in the extract was determined using atomic absorption spectrometry, while the total nitrogen was determined by the macro-kjedahl method (Bremner, 1965).

\section{Statistical Analysis}

Data were collected, averaged and analyzed after which ANOVA was performed on them using GenStat $\left(9^{\text {th }}\right.$ edition) software. 
International Journal of Agriculture

ISSN 2520-4629X (Online)

Vol.5, Issue 1, pp 1 - 24, 2020

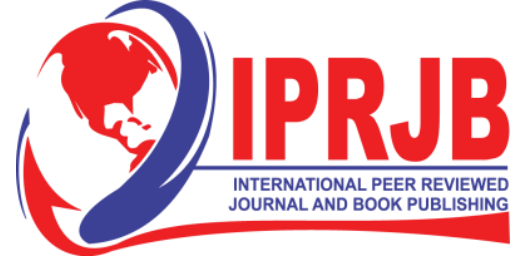

WWW.iprjb.org

\subsection{RESULTS}

\subsection{Physico-chemical characteristics of the soils}

Table 1 gives the physical and chemical characteristics of the soils used for the study. According to the soil particle size analysis, the topsoil of Nzema soil can be classified as sandy clay loam, while that of Adenta soil is clay to sandy clay. The results showed a sand content of $550 \mathrm{~g} / \mathrm{kg}$ in Nzema, which was higher than the $475 \mathrm{~g} / \mathrm{kg}$ in Adenta. The silt content was also higher in Nzema $(125 \mathrm{~g} / \mathrm{kg})$ than in Adenta $(75 \mathrm{~g} / \mathrm{kg})$ while the clay content was lower in Nzema $(325 \mathrm{~g} / \mathrm{kg})$ than in Adenta $(450 \mathrm{~g} / \mathrm{kg})$. The relative composition of Nzema and Adenta followed: Sand $>$ Clay $>$ Silt .The analysis also indicated that Nzema was strongly acidic with a $\mathrm{pH}$ of 4.4 (1:1 soil: water) while Adenta was slightly acidic (pH 6.3).

The organic carbon content of Nzema series $(19.6 \mathrm{~g} / \mathrm{kg})$ was higher than that of Adenta series $(17.5 \mathrm{~g} / \mathrm{kg})$. Total nitrogen was found to be higher in Nzema soil $(2.8 \mathrm{~g} / \mathrm{kg})$ than the Adenta soil $(2.3 \mathrm{~g} / \mathrm{kg})$. Soil extractable Bray-1 in Nzema soil $\left(7.45 \mathrm{mg} \mathrm{P} / \mathrm{kg}^{-1}\right)$ was lower than the Adenta soil (16.1mg P/kg). In general, exchangeable $\mathrm{Ca}^{2+}$ and $\mathrm{Mg}^{2+}$ cations were higher in the Coastal savanna soil (Adenta) than the Nzema soil in the semi-deciduous forest zone, as shown in Table 1. The Nzema soil had higher exchangeable acidity than the Adenta soil

Table 1. Some physico-chemical properties of the topsoil $(0-15 \mathrm{~cm})$ of the Nzema and Adenta series

\begin{tabular}{|c|c|c|}
\hline Properties & Nzema series & Adenta series \\
\hline Sand $\left(\mathrm{gkg}^{-1}\right)$ & 550 & 475 \\
\hline Silt $\left(\mathrm{gkg}^{-1}\right)$ & 125 & 75 \\
\hline Clay $\left(\mathrm{gkg}^{-1}\right)$ & 325 & 450 \\
\hline $\mathrm{pH}$ (water) & 4.4 & 6.3 \\
\hline $\mathrm{pH}\left(0.01 \mathrm{M} \mathrm{CaCl}{ }_{2}\right)$ & 4.2 & 6.1 \\
\hline Total $\mathrm{N}\left(\mathrm{gkg}^{-1}\right)$ & 2.8 & 2.3 \\
\hline Total C $\left(\mathrm{gkg}^{-1}\right)$ & 19.6 & 17.5 \\
\hline Organic matter $\left(\mathrm{gkg}^{-1}\right)$ & 33.7 & 30.1 \\
\hline Available P $\left(\mathrm{mgkg}^{-1}\right)$ & 7.45 & 16.1 \\
\hline \multicolumn{3}{|c|}{ Exchangeable bases $\left(\mathrm{cmol}(+) / \mathrm{kg}^{-1}\right)$} \\
\hline $\mathrm{Ca}^{2+}$ & 2.85 & 3.21 \\
\hline $\mathrm{Mg}^{2+}$ & 2.26 & 2.90 \\
\hline $\mathrm{K}^{+}$ & 0.30 & 0.40 \\
\hline $\mathrm{Na}$ & 0.38 & 0.36 \\
\hline \multicolumn{3}{|c|}{ Exchangeable acidity $\left(\mathrm{cmol}(+) / \mathrm{kg}^{-1}\right.$} \\
\hline $\mathrm{Al}^{2+}$ & 0.40 & 0.30 \\
\hline $\mathrm{H}^{+}$ & 1.38 & 0.40 \\
\hline ECEC & 7.57 & 7.27 \\
\hline (\%) Al saturation & 5.28 & 4.12 \\
\hline
\end{tabular}

\subsection{Effect of TSP and TPR on the dry matter yield of tested crops on both soils}

Figures 1 and 2 show the dry matter yields (DMY) of maize, millet and sorghum obtained under the different $\mathrm{P}$ treatments on the Nzema and Adenta soils, respectively. The growth of the plants 
in both the Nzema and Adenta soils varied with the species, soil type, the $\mathrm{P}$ source and P rates. All the cereal crops showed significant improvement in DM yield with the two rates of TSP application irrespective of the soil type. However, there was no significant difference $(p>0.05)$ in dry matter yield between the $50 \mathrm{mg}$ and $100 \mathrm{mg}$ P/pot rates of TSP. In contrast, the response of the cereal crops to TPR at both $50 \mathrm{mg}$ and $100 \mathrm{mg}$ P/pot was generally very poor and not significant in the two soils (Figs 1 and 2). Among the three crops, response of millet to TPR was low in both Nzema and Adenta soils.

With the TSP application, sorghum in Nzema soil gave the highest dry matter yield (13.62g/pot) followed by maize (10.94g/pot). The trend was sorghum>maize >millet (Fig. 1 and 2). In Adenta series sorghum again produced the highest dry matter yield of $10.06 \mathrm{~g} / \mathrm{pot}$ whilst millet yielded the lowest dry matter $(0.52 \mathrm{~g} / \mathrm{pot})$ in the same soil. The performance trend was thus sorghum $>$ maize >millet, which was similar to that of Nzema soils. Without P fertilizers, average dry matter yield in the Nzema soil, was low, about $1.12 \mathrm{~g}$ per pot.

Figure 2 shows that the DMY of the crops from the control treatments were slightly better in Adenta soil with higher P than in Nzema soil. The results (Figs. 3 and 4) show that the legume crops responded markedly to the addition of the water soluble phosphorus fertilizer. However, the dry matter yields of the crops were significantly different $(\mathrm{p}<0.05)$ under TSP application rates in all the soils, with cowpea giving the highest dry matter yield response to TSP in both the Adenta and the Nzema soils (Figs 3 and 4).

The dry matter yields of soybean and pigeon pea also appeared to respond to TPR application at the two rates even though the responses were not significant. There were no significant differences ( $p>0.05)$ in dry matter yield between the control and the $50 \mathrm{mg} \mathrm{P} / \mathrm{pot}$ rates of TPR application for soybean and pigeon pea in Nzema soil, however, the application of 100mg P/pot produced significant increases the DMY of the crops in both soils. In general, the DMY of the cereal crop species obtained with TSP application followed the trend: Sorghum $>$ maize $>$ millet while the legume crops also followed a trend, cowpea>soybean>pigeon pea. Fairly, a similar trend was obtained with the application of TPR.

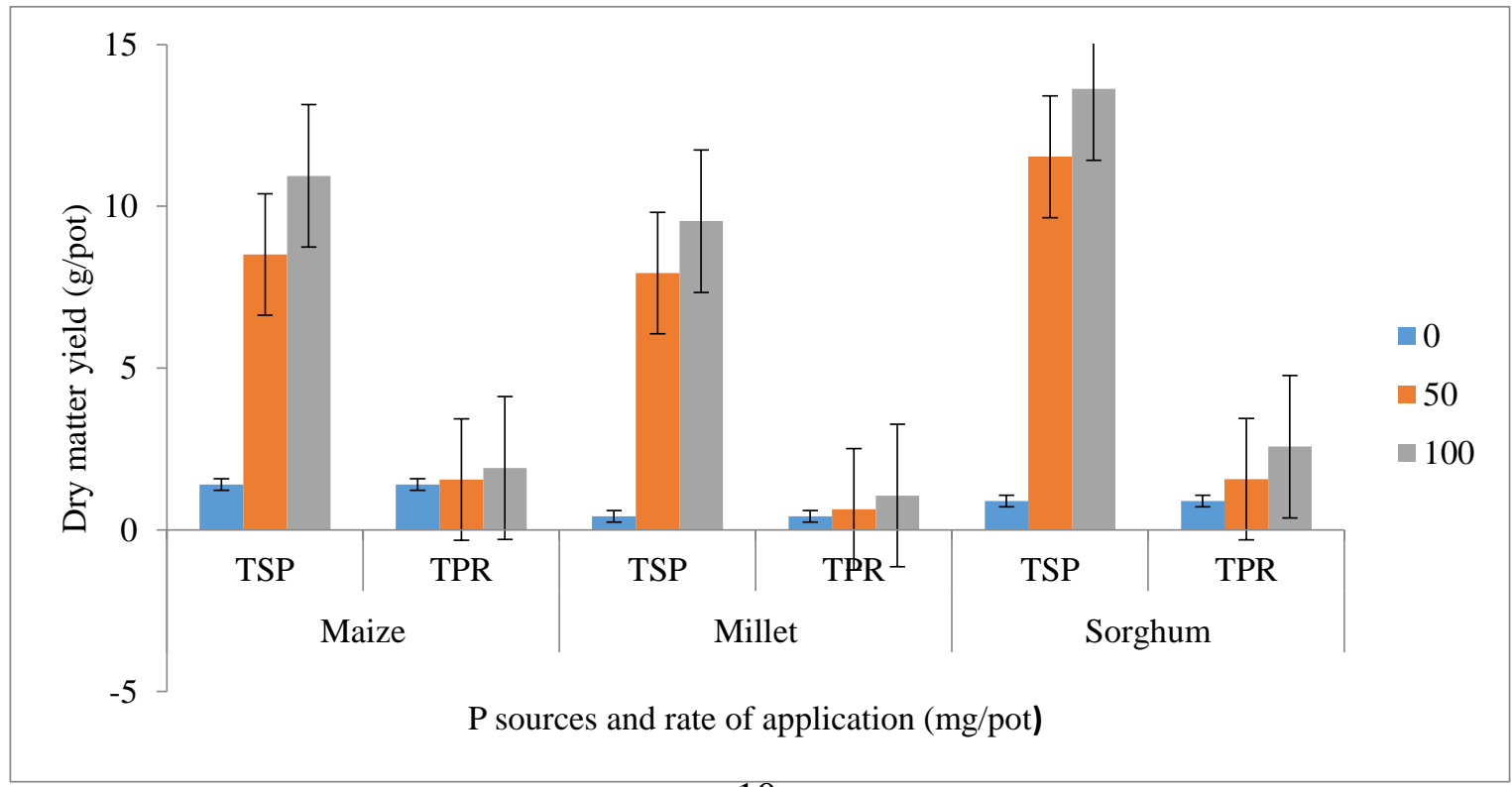


International Journal of Agriculture

ISSN 2520-4629X (Online)

Vol.5, Issue 1, pp 1 - 24, 2020

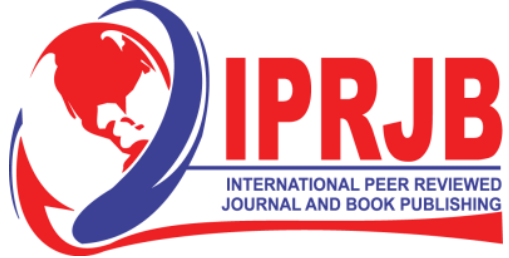

Fig. 1 Effect of TSP and TPR application rates on dry matter yield of maize, millet and sorghum on the Nzema soil

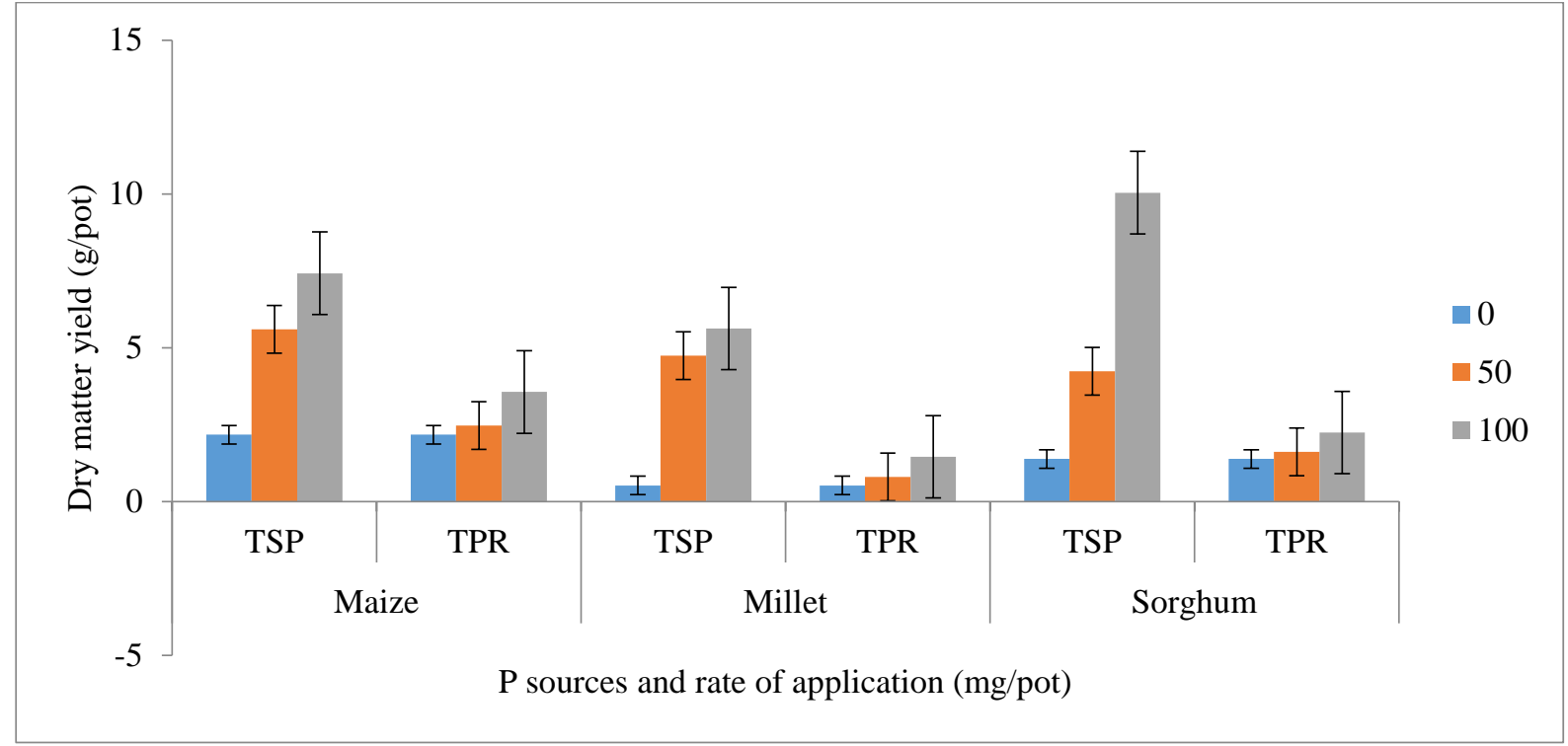

Fig. 2 Effect of TSP and TPR application rates on dry matter yield of maize, millet and sorghum on the Adenta soil

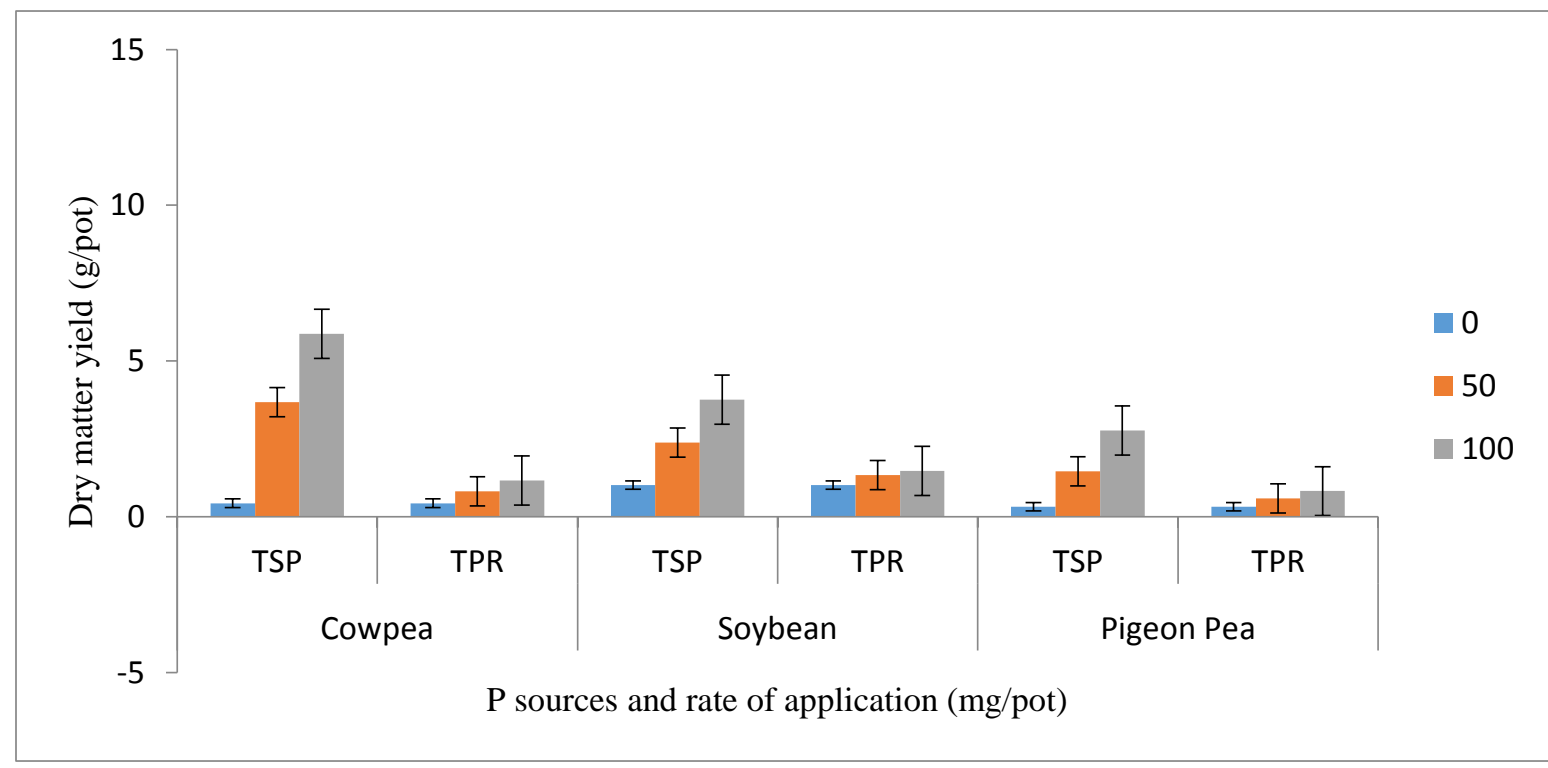

Fig. 3 Effect of TSP and TPR application rates on dry matter yield of cowpea, soybean and pigeon pea on the Nzema soil 


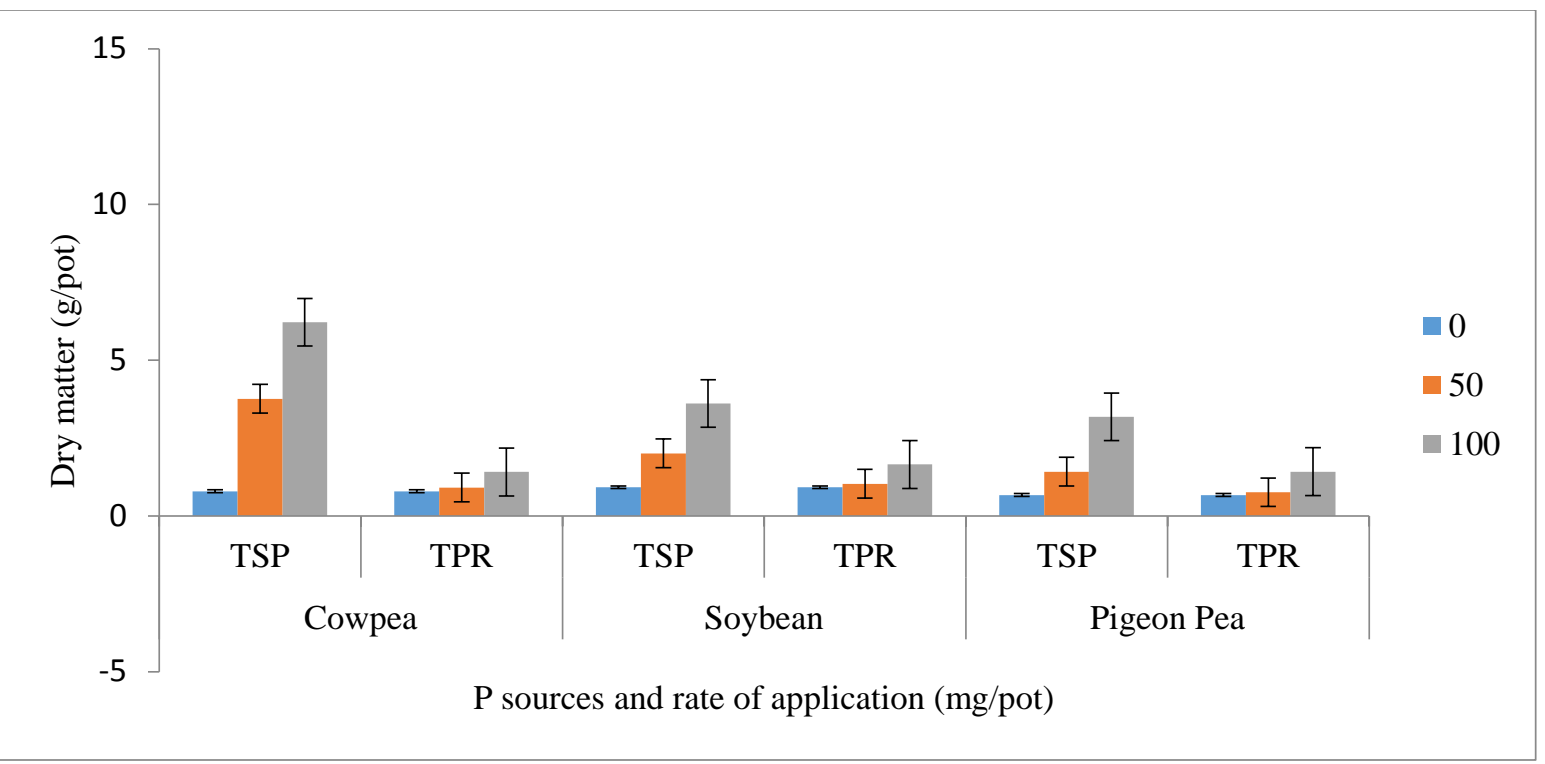

Fig. 4 Effect of TSP and TPR application rates on dry matter yield of cowpea, soybean and pigeon pea on the Adenta soil

\subsection{Effect of TSP and TPR application on $P$ uptake by the six crops}

The effects of TSP and TPR application on P uptake by the six test crops are given in Figs. 5 and 6. Generally, there were significant differences $(\mathrm{p}<0.05)$ in $\mathrm{P}$ uptake by all the three cereal crops in both soils under TSP application. Among the cereals, total P uptake by sorghum was the highest, followed by millet and maize in that sequence in the Nzema soil. In Adenta soil the total $\mathrm{P}$ uptake was again highest with sorghum, but this time followed by maize before millet. Phosphorus uptake by the cereals from the TSP was $25 \%$ higher in the Nzema soil than the Adenta soil. Increasing the $\mathrm{P}$ rates to $100 \mathrm{mg} \mathrm{P} /$ pot increased further the $\mathrm{P}$ uptake by all the cereals. The $\mathrm{P}$ uptake at $50 \mathrm{mg} \mathrm{P} / \mathrm{pot}$ was significantly lower $(\mathrm{p}<0.05)$ and higher at the $100 \mathrm{mg}$ $\mathrm{P} /$ pot rate.

As shown in Figs. 5 and 6 the P uptake by cereal plants did not increase significantly with the application of TPR except for maize in the Adenta soil. Phosphorus uptake by the crops at $50 \mathrm{mg}$ $\mathrm{P} /$ pot was fairly similar to that of their control counterparts in both soils. The data further showed that although not significant in almost all cereals there was the tendency for the P uptake by the crops to increase with an increase in the quantity of TPR applied. In general, the quantity of P taken up by all the cereal crops in TPR treatments was far lower to that for TSP.

Figs. 7 and 8 present the effect of TSP and TPR application on P uptake by the legume crops. The results showed that $\mathrm{P}$ uptake by the crops from TSP increased significantly with the application $50 \mathrm{mg} \mathrm{P} /$ pot $(\mathrm{p}<0.05)$, being in all cases, in both soils. Except for $\mathrm{P}$ uptake by soybean in Nzema, there were significant differences $(\mathrm{p}<0.05)$ in $\mathrm{P}$ uptake between the $50 \mathrm{mg}$ $\mathrm{P} /$ pot and 100mg P/pot rates. The data (Figs. 7 and 8) show that among the legume crops, uptake of $\mathrm{P}$ from the water-soluble $\mathrm{P}$ fertilizer by cowpea was significantly higher than either soybean or pigeon pea, in both soils. The P uptake from the TPR by the legume crops was very low and far less than from TSP. The leguminous crops took very little P from TPR at 50mg P/pot, but the 
International Journal of Agriculture

ISSN 2520-4629X (Online)

Vol.5, Issue 1, pp 1 - 24, 2020

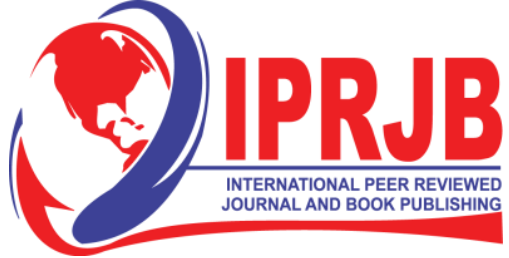

www.iprjb.org

uptake was slightly enhanced with the application of $100 \mathrm{mg} \mathrm{P} /$ pot in all the soils. The cereals in most cases took up more P from the TSP, especially, in the Nzema soil than the legumes.

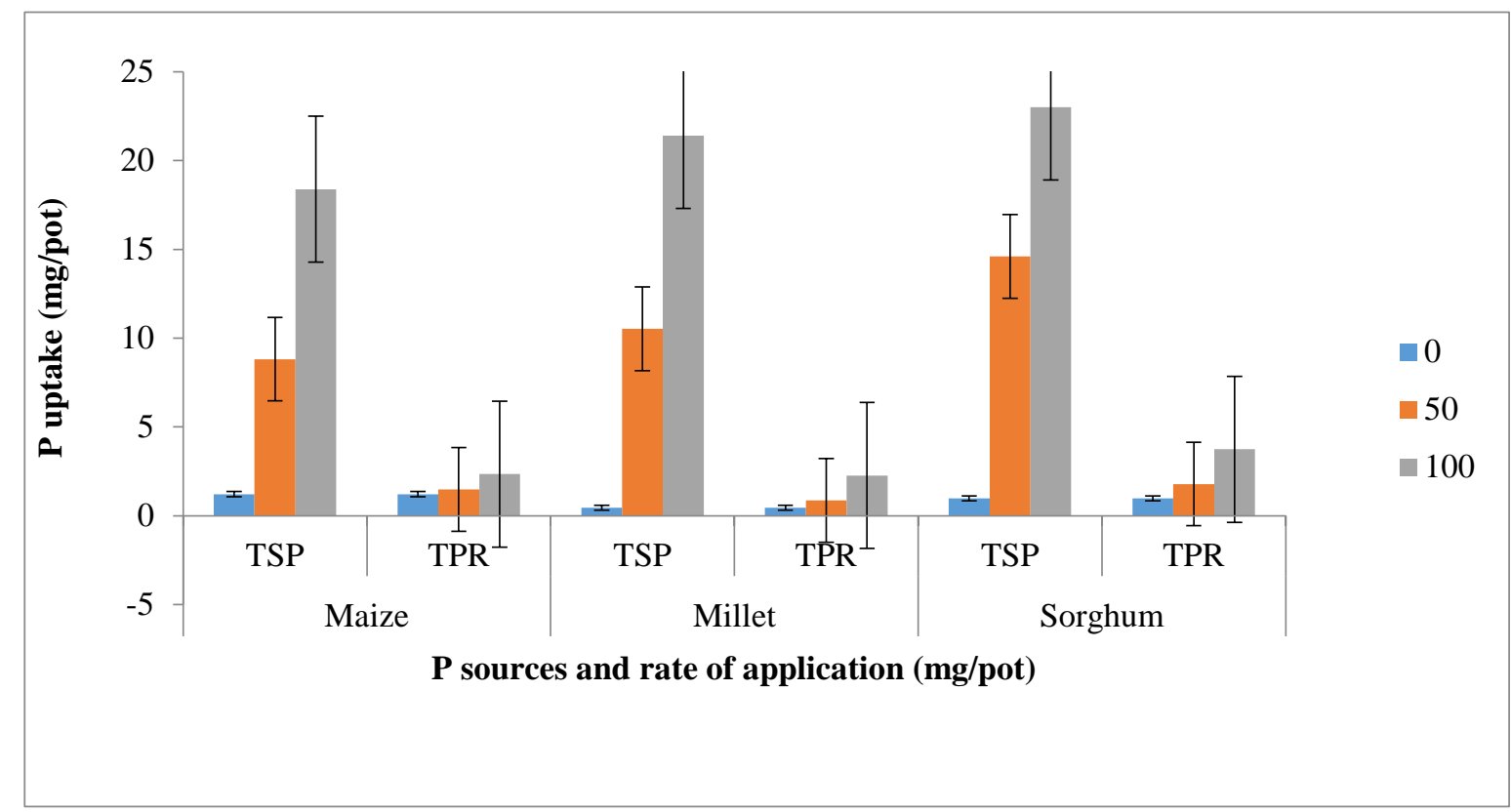

Fig. 5 Effect of TSP and TPR application on P uptake by maize, millet and sorghum in the Nzema soil

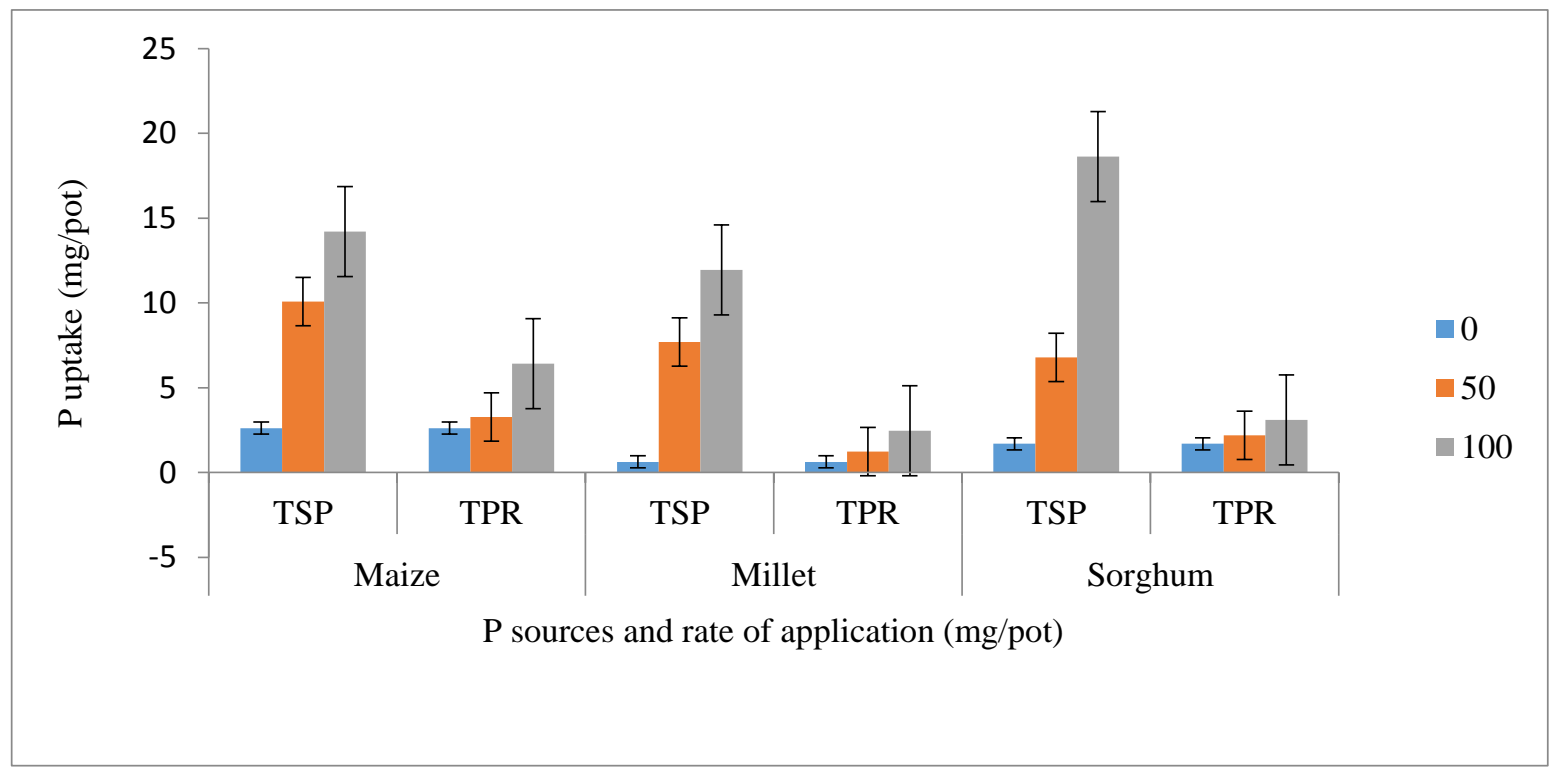

Fig. 6 Effect of TSP and TPR application on P uptake by maize, millet and sorghum in the Adenta soil 
International Journal of Agriculture

ISSN 2520-4629X (Online)

Vol.5, Issue 1, pp 1 - 24, 2020

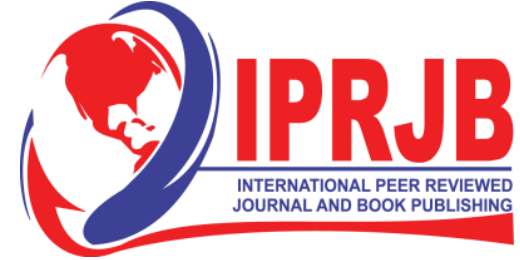

www.iprjb.org

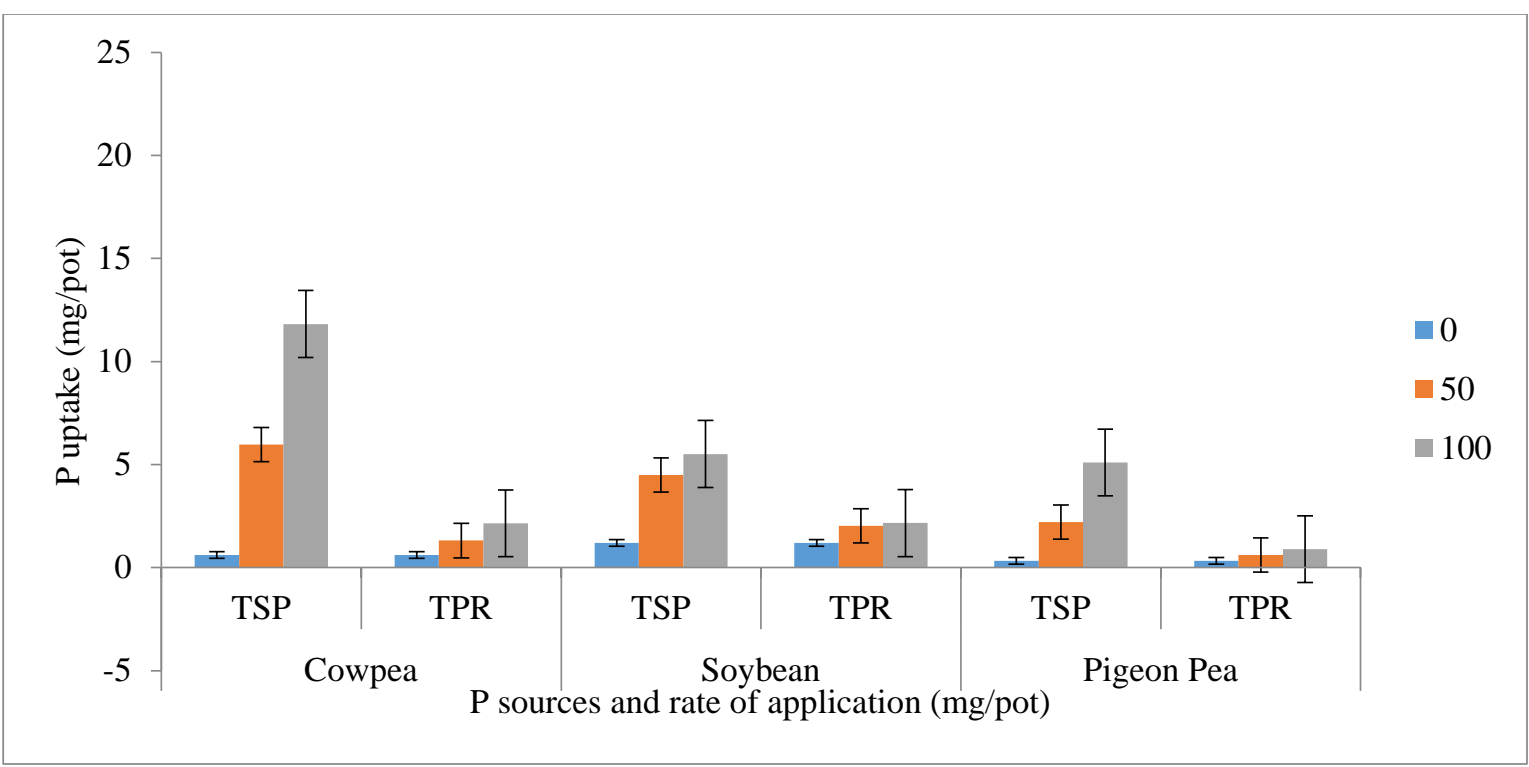

Fig. 7 Effect of TSP and TPR application on $P$ uptake by cowpea, soybean and pigeon pea in the Nzema soil

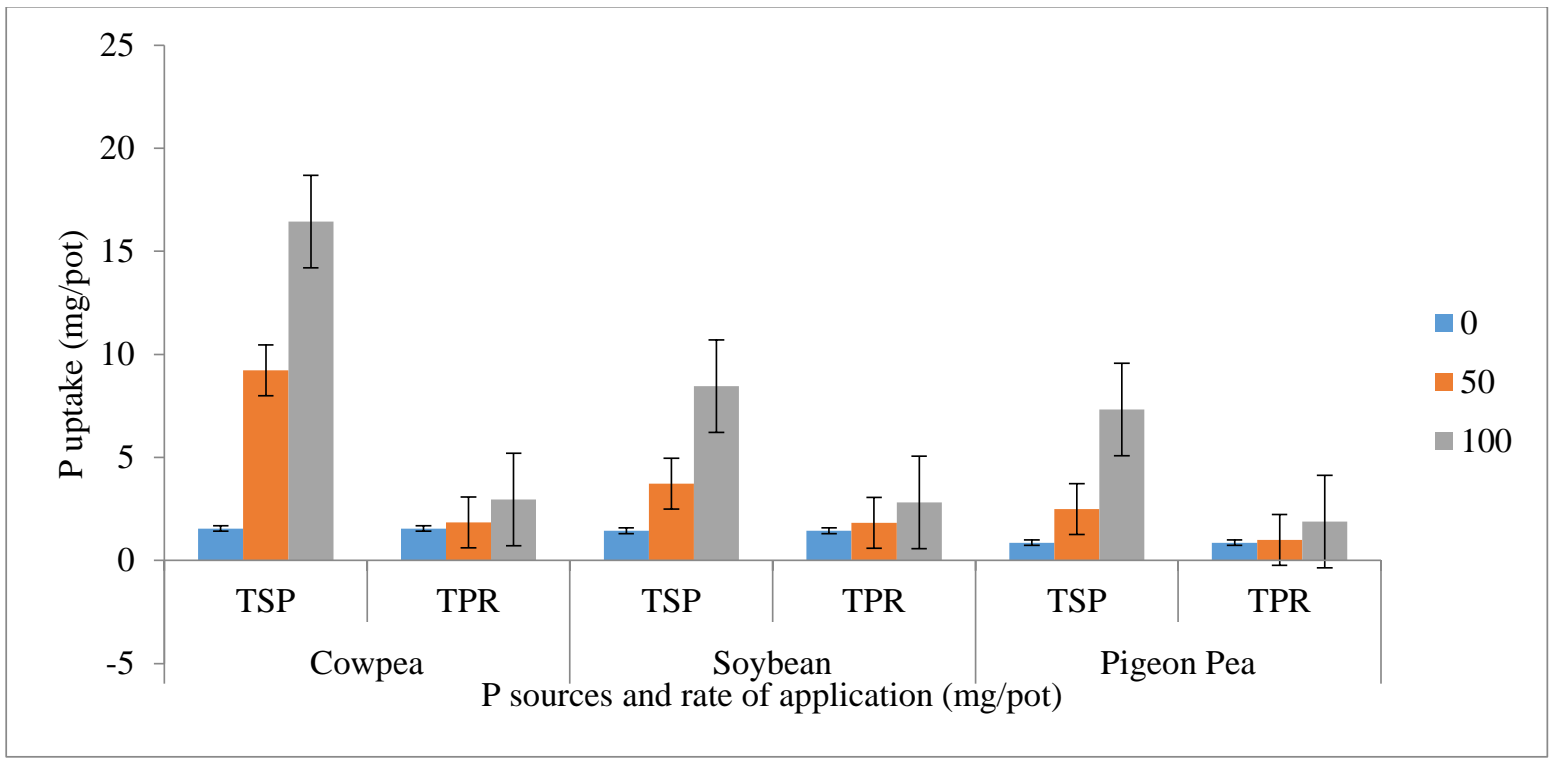

Fig. 8 Effect of TSP and TPR application on P uptake by cowpea, soybean and pigeon pea in the Adenta soil

3.4 Relative Agronomic Efficiency (RAE) of dry matter yield (DMY) of Togo Phosphate Rock on six crops grown in two soils

The relative agronomic efficiency (RAE) of Togo PR relative to the TSP at the two P rates is presented in Table 2. Among the cereals, the RAE of maize on the Adenta series was the highest $(26.3 \%)$ at $\mathrm{TPR}_{100}$ whilst RAE of maize on the Nzema series was the lowest percent. Millet gave 
the second highest RAE (18.2\%) after maize and this occurred in the Adenta soil. Generally, the RAEs of maize and millet were higher in Adenta series than in Nzema series except sorghum, which had RAE higher in Nzema soil than Adenta soil (Table 2). The trend of performance of cereals in terms of their RAE of the dry matter yield followed the trend: sorghum $>$ millet $>$ maize in Nzema soil and maize>millet>sorghum in Adenta (Table 2). The results further showed that increasing the rates of the TPR improved the RAEs of all the crops irrespective of the soil.

Among the legumes, pigeon pea gave the highest RAE of the dry matter yield $(29.9 \%)$ followed by soybean (27.1\%) in the Adenta soil (Table 2). A similar pattern was observed on Nzema soil. The lowest RAE of the dry matter yield was recorded by cowpea on both Nzema and Adenta soil. The RAE was increased with an increase in rate of Phosphorus. This trend was consistent among all the six crops and in the two soils.

\begin{tabular}{|c|c|c|c|c|c|c|}
\hline \multicolumn{7}{|l|}{ Treatments } \\
\hline (mg/pot) & & & RAE (\%) & & & \\
\hline Nzema soil & Maize & Millet & Sorghum & Cowpea & Soybean & Pigeon pea \\
\hline 50 & 2.11 & 2.79 & 6.39 & 11.69 & 24.08 & 23.89 \\
\hline 100 & 5.35 & 7.02 & 13.20 & 13.42 & 16.73 & 20.41 \\
\hline \multicolumn{7}{|l|}{ Adenta soil } \\
\hline 50 & 8.75 & 6.40 & 8.07 & 4.04 & 10.09 & 12.00 \\
\hline 100 & 26.32 & 18.24 & 9.91 & 12.89 & 27.14 & 29.88 \\
\hline RAE & $(\%)$ & & & & Agronon & \\
\hline
\end{tabular}

\section{Discussion}

\section{Physicochemical properties of Nzema and Adenta soil}

The Nzema series used in the study was more acidic than Adenta and the low $\mathrm{pH}$ of the Nzema soil may be attributed to the nature of the parent materials and partly to the intense leaching of bases caused by the high precipitation in the semi-deciduous zones. The high exchangeable acidity of the Nzema soil conforms to its low $\mathrm{pH}$ and moderate Al saturation. The low $\mathrm{pH}$ and moderate Al saturation of the Nzema soil may imply that there is a need for $\mathrm{P}$ application in order to improve crop growth on the soil because fairly high exchangeable $\mathrm{H}^{+}$and $\mathrm{Al}$ cations in soil do significantly affect plant growth (Buol et al., 1973). The relatively higher organic carbon content of the Nzema soil was consistent with the observation that surface soils from the uncultivated forest soils have higher organic carbon content than those from the coastal savanna soil (Jones \& Wild, 1957). The available P in the Adenta soil was found to be within the critical range suggested by Sahrawat et al (1997) while that of the Nzema soil was below the critical range.

\section{Effect of TSP and TPR on the growth of plant (dry matter yield)}

Differences in the dry matter yield of the crops from both soils treated with the different $\mathrm{P}$ sources were primarily due to the differences in the water-soluble $\mathrm{P}$ contents of the fertilizers 
used and other factors such as $\mathrm{pH}$, crop species and available $\mathrm{P}$. Characterization of the fertilizers indicated that triple superphosphate had the highest soluble P (with water solubility of 98\%) while Togo Phosphate Rock was almost insoluble in water; hence TSP application gave the higher dry matter yield in both soils whilst lower dry matter yield was realized with TPR application. These differences reflected in early plant development, promoting higher root formation, cell enlargement and subsequently higher dry matter by TSP (Khasawneh \& Doll, 1978; Paul, 1988).

Without $\mathrm{P}$ addition, the dry matter yields of the crops were very low, indicating the very low available P in the soils. Dry matter yield was higher in the Nzema soil than the Adenta soil under TSP application rates. The higher dry matter yields of the cereals obtained from the Nzema soil with the TSP could be attributed to the high level of organic matter and total nitrogen in the Nzema soil coupled with the supply of soluble P which was deficient.

It has also been suggested that at higher levels of $\mathrm{P}$ application, as the solution $\mathrm{P}$ increases above the threshold concentration for net P uptake by plants, crop yield rises steeply (Rajan, 1973; Fox et al., 1986) and this increment of $\mathrm{P}$ content coupled with high organic matter and total nitrogen content might have ensured higher dry matter yield obtained in this study. The organic ions in the organic matter and humus can also reduce $\mathrm{P}$ sorption capacity of soils by blocking $\mathrm{P}$ sorption sites and by forming complexes with iron and aluminum hydrous oxides, leading to increased $\mathrm{P}$ concentration in solution (Manickam, 1993) resulting in higher dry matter being realized. The maximum yield obtained by the different $\mathrm{P}$ sources at the same level of application was in order TSP>TPR implying that maximum dry matter yield was a function of solubility (Butegwa et al, 1996).

Generally, P uptake from TPR at the two rates is expected to have been high in the Nzema soil because of low solution concentration of $\mathrm{Ca}$, low $\mathrm{P}$ fertility levels and high organic matter content, but the situation turned out to be the opposite for all the cereals except sorghum at $\mathrm{TPR}_{100}$. These opposite effects realized for maize and millet in the Nzema soil is similar to the findings of Wild (1995), Owusu-Bennoah (1997) and Dakora et al (2002) who showed that dry matter yield of crops was low despite $\mathrm{P}$ application in acid soils. The behaviour of the cereals on the two soils is supported by a similar observation by Frederick et al. (1992) and Lompo et al., (1994). The significant performance of maize and millet on the Adenta soil may be due to the high level of available $\mathrm{P}$ which promoted the early development of root and better growth of the crop and subsequently higher $\mathrm{P}$ uptake.

The results from the study showed a positive relationship between shoot dry matter yields, $\mathrm{P}$ uptake and $\mathrm{P}$ application. Legumes compared to the control produced significantly higher dry matter yield on both soils, with both TSP and TPR application. The positive effect on the legumes with respect to dry matter yield from TPR treatments could be due to the augmentation ability of $\mathrm{P}$ absorbed from sparingly soluble soil with fertilizer $\mathrm{P}$, which eventually led to increase in the shoot dry matter yield (Horst et al. 2001; Krasilnikoff et al, 2003; Nuruzzaman et al, 2005; Bekele et al., 1983; Haynes, 1983, 1992).

The improvement in the dry matter yield of pigeon pea and cowpea on Adenta soil and soybean on the Nzema soil at $\mathrm{TPR}_{50}$ and $\mathrm{TPR}_{100}$ shows the importance of Phosphorus application to dry matter yield of legumes. Significant difference that was shown by cowpea on Nzema soil could 
be attributed to the ability of the crop to desorp P from sparingly available $\mathrm{P}$ sources through exudation of high amounts of organic acid anions, mainly citrate (Gerke et al, 1992). The dry matter yield of TPR was very far inferior to that of TSP because of the low solubility of the TPR.

\section{Effect of TSP and TPR application rates on $P$ uptake by the six crops}

Phosphorus uptake by maize and millet from TPR on the Nzema soil was lower than for sorghum. This is in agreement with the assertion that although PR dissolution may be increased by a high P sorption capacity of the soil, PR effectiveness is lower in such soils (Mokwunye and Hammond, 1992). Hammond et al. (1986) ascribed this poor performance of PRs in soils with high $\mathrm{P}$ sorption capacity to poor root development during the early stages of crop growth due to $\mathrm{P}$ deficiency. The improvement in performance of maize and sorghum with TPR rates in the Adenta soil may, probably, be due to their root morphology, specifically, their root density.

According to Chien et al (1990), plants with higher root densities in the surface layers of the soil are better able to acquire dissolved P from PR because of the greater volume of soil the root system can explore. The significant performance of maize with TPR in the Adenta soil, which turned out to be the highest $\mathrm{P}$ uptake by the cereals may be attributed to its high root densities as well as its ability to excrete of organic acids (Nene and Shiela, 1990; Okalebo et al., 2002; Campaore et al., 2011).

Control treatments in the Adenta soil performed better in its $\mathrm{P}$ uptake than their counterparts in the Nzema soil. It may be due to the higher level of available P in the original Adenta soil which may have enhanced early development of the roots of the crops examined. This effect resulted in higher shoot dry matter yield in the Adenta soil and it confirm the important role P availability plays in terms of P uptake and dry matter yield of crops (Marschner, 1993).

Togo Phosphate Rock application to legumes resulted in higher P uptake in the Nzema soil than the Adenta soil. It has been suggested that some legume genotypes, especially cowpea, have the capacity to acidify the rhizosphere. The acidification of the rhizosphere due to concomitant release of protons for maintaining the charge balance would contribute particularly to the solubilization of the PR applied as P fertilizer (Gerke et al. 2000; Kania et al 2003; Neumann and Romheld 1999; Bekele et al., 1983; Hinsinger and Gilkes, 1997).

In a study to investigate phosphorus benefits from grain-legume crops to subsequent maize grown on acid soils of southern Cameroon it was observed that enhanced exudation of organic acid anions and root surface phosphatase activity served as important plant traits for genotypic $\mathrm{P}$ acquisition efficiency (Jemo et al. 2006; Hoffland, 1992). It has been suggested that in this way, legumes revalue the PR into a more available $\mathrm{P}$ source.

\section{Relative Agronomic Efficiency (RAE) of Togo Phosphate Rock relative to TSP}

The high RAEs with TPR in dry matter yield and total P of cowpea, soybean and pigeon pea relative to TSP on the Nzema soil was as a result of the fact that crops with lower P demands, such as legume crops, tended to have higher RAE than cereals. The data is supported by Khasawneh and Sample (1979) who suggested that the concentration of soil solution P required by cowpea for maximum growth potential may be only two-thirds the concentration required by maize. According to Chien et al (1995), the RAE of PR would be higher for crops with lower P demands, such as legume crops than for cereal crops, such as maize, supporting the data for this 
study. Different research results (Bationo et al, 1986) have shown that leguminous crops are more efficient in using PR than cereals. The low level of $\mathrm{P}, \mathrm{Ca}$ and $\mathrm{pH}$ serve as precursors for $\mathrm{P}$ dissolution, thus Nzema soil, having these features, was able to dissolve more P from TPR.

The high legumes RAE of TPR relative to TSP could also be explained by the fact that they have the capacity to acidify the rhizosphere. The acidification of the rhizosphere due to concomitant release of protons for maintaining the charge balance would contribute particularly to the solubilization of unreactive PR applied as P fertilizer (Gerke et al. 2000; Kania et al 2003; Neumann and Romheld 1999; Bekele et al., 1983; Hinsinger and Gilkes, 1997). The above explanation could further be used to account for TPR dissolution in the Coastal savanna soil (Adenta soil) with a $\mathrm{pH}$ of 6.3 contrary to the view that the dissolution of PR diminishes with increasing $\mathrm{pH}$ up to 5.5 but declines more rapidly above this $\mathrm{pH}$ level (Bolan and Hedley, 1990).

The study also showed that maize and millet did better in the Adenta soil in terms of RAE with TPR in their dry matter yield, and P uptake with increased P rate. This is in agreement with the work of Khasawneh and Sample (1979) that cereals require and take up more P where available. The available $\mathrm{P}$ in the Adenta soil might have been taken by these crops to increase the effectiveness of PR utilization. The high RAE with TPR in sorghum dry matter yield in Nzema soil might be due to the root density of the crops and also the inherent capacity of the soil to make $\mathrm{P}$ available due to its low $\mathrm{pH}$ level. The agricultural effectiveness of TPR for all the crops proved the low reactivity of the material and its subsequent low performance compared with the water-soluble P (Bationo et al,. 1986; Bationo and Mokwunye, 1991; Bationo and Kumar, 1999).

The low reactivity of the Togo PR may be attributed to the high molar ratio $\mathrm{PO}_{4}{ }^{-} / \mathrm{CO}_{3}$ of the material (Roy and McCallan, 1986). According to Gachon (1977) and Mokwunye (1994) a molar mass of $\mathrm{PO}_{4} / \mathrm{CO}_{3}$ less than 5 is an indicator of phosphorus solubilization of PR. The increased RAE of Togo PR with increased $P$ rate may seem to suggest that there was enough solubilized $P$ available for the crops. Similar results have been reported by Bonzi et al, (2011).

\subsection{CONCLUSIONS AND RECOMMENATIONS}

\section{Conclusion}

Conclusively, increasing the rate of TPR to $100 \mathrm{mg} \mathrm{P} /$ pot resulted in an increase in dry matter yield and P uptake in both soils, but was inferior to $100 \mathrm{mg} \mathrm{P} /$ pot TSP application. It is therefore imperative to make sure that the rate of application of TPR should always be high if farmers wants the best from their lot. Again it is seen that the agricultural effectiveness of TPR for all the crops proved the low reactivity of the material and its subsequent low performance compared with the water-soluble P. The results from these studies show that unreactive Togo PR cannot be used as a substitute for TSP in cereal/legume cropping systems. The low reactivity and the high molar mass of $\mathrm{PO}_{4}{ }^{3-} / \mathrm{CO}_{3}{ }^{2-}$ make it unsuitable for direct application.

\section{Recommendations}

Future work should increase the TPR rates and conduct over a long period. Follow up work can also be done to determine the level of other inexpensive rock phosphate sources such as Gafsa PR and Tilemsi PR required for optimal growth. In a further step, research should be targeted at screening for high potential N-fixing legumes and cereals with ability to excrete organic acids for 
International Journal of Agriculture

ISSN 2520-4629X (Online)

Vol.5, Issue 1, pp 1 - 24, 2020

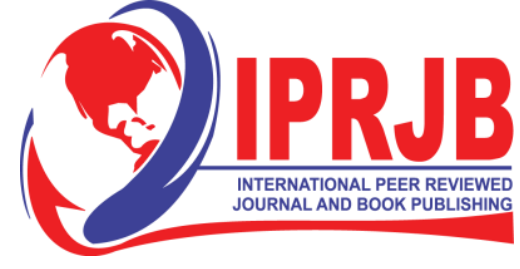

www.iprjb.org

their ability to mobilize $\mathrm{P}$ from the various PR deposits in West Africa. In this pot experiment the small volume of $1 \mathrm{~kg}$ soil per pot used might be a limiting factor, because the soil was rapidly explored by plant roots before they achieved their maximum development. Therefore it will useful to repeat this kind of experiment with $5 \mathrm{~kg}$ soil per pot that might favour a better growth of plants. More research work is needed to evaluate the agronomic effectiveness of Togo PR, especially under field trials for long term effects.

Acknowledgement: My sincere appreciation goes to Dr. (Mrs.) Rosemary Entua Mensah, the Deputy Director-General, Council for Scientificbutegwa and Industrial Research (CSIR) and the Coordinator of the West African Agricultural Productivity Programme (WAAPP) for providing a financial package for this work.

\section{REFERENCES}

Adams, M. A. \& Pate, J. S. (1992). Availability of organic and inorganic forms of phosphorus to lupins (Lupinus spp.). Plant soil, 145:107-113.

Ae, N., Arihara, J., Okada, K., Yoshihara, T. \& Johansen, C. (1990) Phosphorus uptake by pigeon pea and its role in the cropping systems of the Indian subcontinent. Science, 248: 477-480

Amankwa, S. (2010). Uptake of phosphate from PR by Nerica Rice in Kokofu series. An M Phil thesis submitted to University of Ghana. Pp 26.

Ankomah, A., B. Zapata, F., Danso S. K. A. \& Axmann, H. (1995). Cowpea varietal differences in uptake of phosphorus from Gafsa phosphate rock in a low P ultisol. Fert. Res., 41:219-225

Baah, F. A. (2010) Morphology and Classification of Adenta series under two management systems. A thesis submitted to University of Ghana. Pp 16

Bationo, A., Lompo, F. \& Koala, S. (1998) Research on nutrient flows and balances in West Africa: state-of-the-art. Agriculture, Ecosystems and Environment 71, 19-35

Bationo, A. \& Mokwunye, A. U. (1991) Alleviating soil fertility constraints to increased food production in West Africa: the experience in the Sahel. In: Mokwunye, A.U. (ed.)

Bekele, T., Cino, B. J., Ehlert, P. A. I.. Van der Maas, A. A. \& Van Diest, A. (1983). An evaluation of plant-borne factors promoting the solubilization of alkaline rock phosphates. Plant Soil, 75: 361-378.Alleviating Soil Fertility Constraints to crop production in West Africa. Kluver Academic Press, Dordrecht, The Netherlands, pp. 195-215.

Bouyoucos, G. J. (1962). Hydrometer method improved for making particle size analysis of soils. Agron. 54: 464-465.

Bremner, J. M. (1965) Total nitrogen. In: Methods of Soil Analysis Part 2. Chemical and Microbiological properties. Black, C. A. (eds). Agronomy monograph 9. Pp 11491178 
Buol, S. W., Hole, F. D., \& McCracken, R. J. (1973). Soil Genesis and Classification, pp: 22.31. Iowa State Univ., Press, Iowa.

Butegwa, C. N., Mullins G. L., \& Chien S. H. (1996) Agronomic evaluation of fertilizer products derived from Sukulu Hills Phosphate Rock. Fertilizer Research. 44:113122

Chien, S. H., \& Hammond, L. L. (1978). A comparison of various laboratory methods for predicting the agronomic potential of phosphate rock for direct application. Soil Sci. Soc. Am. J., 42: 1758-1760.

Chien, S. H., \& Hammond, L. L. (1989). Agronomic effectiveness of partially acidulated phosphate rock as influenced by soil phosphorus-fixing capacity. Plant Soil, 120: 159-164.

Chien, S. H., Sale, P. W. G., \& Friesen, D. K (1990) A discussion of the methods for comparing the relative effectiveness of phosphate fertilizers varying in solubility. Fertilizer Research. 24: 149-157.

Chien, S. H., Sale, P. W. G., \& Hammond, L. L. (1990b). Comparison of effectiveness of various phosphate fertilizer products. In Proceedings of international symposium on phosphorus requirements for sustainable agriculture in Asia and Oceania, pp. 143-156. Manila, IRRI.

Chien, S. H. (2003). Factors affecting the agronomic effectiveness of phosphate rock: a general review. In S.S.S. Rajan \& S.H. Chien, eds. Direct application of phosphate rock and related technology: latest developments and practical experiences. Proc. Int. Meeting, Kuala Lumpur, 16-20 July 2001. Muscle Shoals, USA, IFDC. 441 Pp.

Chien, S. H. (2003). IFDC's evaluation of modified phosphate rock products. In Proceedings of international meeting on direct application of phosphate rock and related technology: latest developments and practical experiences. Kuala Lumpur, Malaysian Society of Soil Science, and Muscle Shoals, USA, IFDC.

Chien, S. H., Singh, U., Van Reuler, H., \& Hellums, D. T. (1999). Phosphate rock decision support systems for sub-Saharan Africa. Special issue on Soil Fertility. Afr. Fert. Mark, 12: 15-22

Chien, S. H., Sale, P. W. G., \& Friesen, D. K. (1990a). A discussion of the methods for comparing the relative effectiveness of phosphate fertilizers varying in solubility. Fert. Res., 24: 149-157.

Chien, S. H., \& Menon, R. G. (1995). Factors affecting the agronomic effectiveness of phosphate rock for direct application. Fert. Res., 41:227-234

Coleman, N. T., Weed, S. B., \& Cracken, R. J. (1959). Cation exchange capacity and exchange cations in pledmont soils of North Carolina. Soil Sci. Soc. Am. Proc., 23: 146-149 
Compaore, E., Fardeau, J. C., \& Morel, J. L. (2011). Greenhouse Evaluation of Agronomic Effectiveness of Unacidulated and Partially Acidulated Phosphate Rock from Kodjari and the Effect of Mixed Crop on Plant P Nutrition. Pp 591-596

Dakora F. D., \& Philips D. (2002). Root exudates as mediators of mineral acquisition low nutrient soils. Plant Soil, 245: 35-47.

Danso, S. K. A. (1977). The ecology of Rhizobium and recent advances in the study of ecology of Rhizobium, In: Ayanaba A. and Dart P. J. (EDS). Biological nitrogen fixation in farming systems of the Humid Tropics. Pp 115-125. John Wiley and Sons.

Diata, A. (2014). Impact of rock phosphate enriched compost (RP-EC) and phosphate solubilizing microorganisms (PSM) on nodulation, growth and yield of chickpea and lentil. $\mathrm{PhD}$ thesis, University Of Agriculture, Faisalabad.

Fox, R. L., Saunders, W. M. H., \& Rajan, S. S. S. (1986). Phosphorus nutrition of pasture species: phosphorus requirement and root saturation values. Soil Sci. Soc. Am. J., 50: $142-148$.

Gerke, J (1992) Phosphate, aluminium and iron in the soil solution of three different soils in relation to varying concentration of citric acid. Z Pflanzenernahr Bodenk 155:339-343

Gerner, H., \& Baanante, C. A. (1995) Economic aspect of phosphate rock application for sustainable agriculture in West Africa. In: Gerner, H. Mokwunye, A.U. (eds) Use of Phosphate Rock for Sustainable Agriculture in West Africa. IFDC, Miscellaneous Fertilizer Studies No. 11, pp. 134-141.

Giller, K. E. (2001) Nitrogen fixation in tropical cropping system, $2^{\text {nd }}$ edition. CABI International, Willingford, U.K. Pp 88, 254-257.

Habib, L., Chien, S. H., Carmona, G., \& Henao, J. (1999). Rape response to a Syrian phosphate rock and its mixture with triple superphosphate on a limed alkaline soil. Com. Soil Sci. Plant Anal., 30: 449-456.

Hammond, L. L., Chien, S. H., \& Mokwunye, A. U. (1986b). Agronomic value of unacidulated and partially acidulated phosphate rocks indigenous to the tropics. Adv. Agron., 40: 89-140.

Haynes, R. J. (1992). Relative ability of a range of crop species to use phosphate rock and monocalcium phosphate as P sources when grown in soil. J. Sci. Food Agric., 74: $1-7$.

Hinsinger, P. (1998). How do plant roots acquire mineral nutrients? Adv. Agron., 64: 225-265.

Hinsinger, P., \& Gilkes, R. J. (1995). Root-induced dissolution of phosphate rock in the rhizosphere of lupins grown in alkaline soil. Aus. J. Soil. Res., 33: 477-489

Hoffland, E. (1992). Quantitative evaluation of the role of organic acid exudation in the mobilization of rock phosphate by rape. Plant Soil, 140: 279-289

Horst W. J., \& Waschkies, C. (1987). Phosphorus nutrition of spring wheat in mixed culture with white lupin. Z. Plaenz. Bodenk., 150: 1-8. 
Horst, W. J., Kamh M., Jibrin, J. M., \& Chude, V. O (2001) Agronomic measures for increasing P availability to crops. Plant Soil 237:211-223

Hungaria, M., \& Vargas, M. A. T. (2000) Environmental factors affecting $\mathrm{N}_{2}$-fixation in grain Legumes in the tropics with emphasis on Brazil. Field Crops Research. 65: 151164. International Fertilizer Development Center (IFDC), (1984). Circular IFDC -

Jemo, M., Abaidoo, R. C., Nolte, C., Tchienkoua, M., Sanginga, N., \& Horst, W. J., (2006). Phosphorus benefits from grain-legume crops to subsequent maize grown on acid soils of Southern Cameroon. Plant Soil 284: 385-397

Jones, M. J., \& Wild .A. (1957). Soils of the West Africa Savanna. Commonwealth Agricultural Bureaux. Farnham Royal, Slough. First Edition. pp246

Jones, D. L. (1998). Organic acids in the rhizosphere - a critical review. Plant Soil, 205: 25-44.

Kamh, M., Horst, W. J., Amer, F., Mostafa, H., \& Maier, P. (1999). Mobilization of soil and fertilizer phosphate by cover crops. Plant Soil, 211: 19-27.

Kania, A., Langlade N, Martinoia, E., \& Neumann, G. (2003). Phosphorus deficiencyinduced modifications in citrate catabolism and in cystosolic $\mathrm{pH}$ as related to citrate exudation in cluster roots of white lupin. Plant Soil 248:117-127.

Khasawneh, F. E., \& Doll, E. C. (1978). The use of phosphate rock for direct application to soils. Adv. Agron., 30: 159-206

Krasilnikoff, G., Gahoonia, T., \& Nielsen, N. E. (2003). Variation in phosphorus uptake efficiency genotypes of cowpea (Vigna unguiculata) due to differences in root and root hair length and induce rhizosphere processes. Plant Soil 251:83-91

Kuyvenhoven, A., \& Lanser, P. (1999). Economic criteria for public investment in phosphate rock application for soil fertility improvement with emphasis on Sahelian countries. African Fertilizer Market 12, 4-22.

Lompo, F., Sedogo, M.P. \& Hien, V. (1995). Agronomic impact of Burkina phosphate and dolomite limestone. In H. Gerner \& A.U. Mokwunye, eds. Use of phosphate rock for sustainable agriculture in West Africa, pp. 54-66. Miscellaneous Fertilizer Studies No. 11. Muscle Shoals, USA, IFDC Africa.

Manickam, T.S. (1993). Organics in soil fertility and productivity management. In P.K. Thampan, ed. Organics in soil health and crop production, pp. 87-104. Cochin, India, Peekay Tree Crops Developments Foundation

Marschner, H. (1993). Mineral nutrition of higher plants. London, Academic Press Ltd., Harcourt Brace \& Co. Publishers.

Mokwunye, A. U., Chien, S. H., \& Rhodes, E. (1986). Phosphate reactions with tropical African soils. In: management of Nitrogen and Phosphorus Fertilizers in Sub Sahara Africa. Mokyunye, A. U. and Vlek Paul. L. G. (eds) Martinus Nijhoff Publishers. Pp 253-281 
Montenegro, A., \& Zapata, F. (2002). Rape genotypic differences in P uptake and utilization from phosphate rocks in an andisol of Chile. Nut. Cyc. Agroecosys. 63(1): 27-33.

Murphy, J., \& Riley, J. P. (1962). A modified single solution method for the determination of phosphorus in natural waters. Anal. Chim. Acta. 27: 31-36.

Nene, Y. L., \& Sheila, V. K. (1990). Pigeon pea, Geography and importance. Pp: 1-12. In: The pigeon pea (Nene, Y. L., Hall, S. D. and Sheila, V. K. eds). Wallingford, U.K: CAB International

Neumann, G., \& Romheld, V. (1999). Root excretion of carboxylic acids and protons in phosphorus-deficient plants. Plant Soil 211:121-130

Nuruzzaman, M., Lambers, H., Bolland, M. D. A., \& Veneklass E. J. (2005). Phosphorus benefits of different legume crops to subsequent wheat grown in different soils of Western Australia. Plant Soil 271:175-187

Okalebo, J. R., Gathua, W. K., and Woomer, P. L. (2002). Laboratory Methods of Soil and Plant Analysis: A Working Manual, $2^{\text {nd }}$ edn. TSBF-CIAT and SACRED Africa, Nairobi, Kenya. 126 Pp.

Owusu-Bennoah, E., Zapata, F., \& Fardeau, J. C. (2002). Comparison of greenhouse and P isotopic laboratory methods for evaluating the agronomic effectiveness of natural and modified rock phosphates in some acid soils of Ghana. Nut. Cyc. Agroecosys., 63(1): 1-12.

Owusu-Bennoah, E., \& Szilas, C., Hansen, H. C. B., \& Borggaard, O. K. (1997). Phosphorus sorption in relation to aluminium and iron oxides of Oxisols from Ghana. Commun. Soil. Sci. Plant Anal,. 28: 685-697

Paul, I. (1988). Caracterisation physico-chimique et evaluation de l'efficacite agronomique de phosphates bruts ou partiellement acidifies provenant d'Afrique de l'Ouest. These Doct. Sci. INPL, Nancy.

Petersen, W., Bottger, M. (1991). Contribution of organic acids to the acidification of rhizosphere of maize seedlings. Plant Soil 132:159-163

Rajan, S. S. S. (1973). Phosphorus adsorption characteristics of Hawaiian soils and their relationships to equilibrium concentrations required for maximum growth of millet. Plant Soil, 39: 519-532

Randhawa, P. S. (2003). Influence of green manuring and phosphate rock inputs on soil phosphorus cycling and availability. PhD Thesis, pp 82-101. (Lincoln University).

Sale, P. W. G., \& Mokwunye, A. U. (1993). Use of phosphate rocks in the tropics. Fert. Res., 35: $33-45$.

Sahrawat, K. L., Abekoe, M. K., \& Diatta. S. (2001). Application of Inorganic Phosphorus Fertilizer. Soil Sci.Soc. Am \& Am. Soc. Agron., SSSA Special Publication NO. 58. Pp 225-246. 
International Journal of Agriculture

ISSN 2520-4629X (Online)

Vol.5, Issue 1, pp 1 - 24, 2020

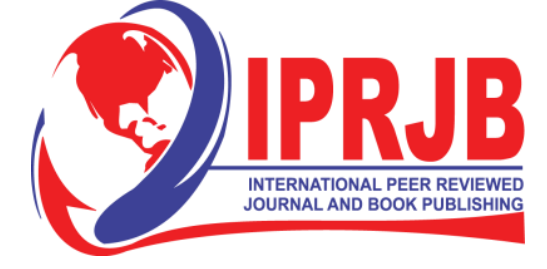

www.iprjb.org

Sahrawat, K. L., Jones, M. P., \& Diatta. S. (1997). Extractable phosphorus and rice yield in ultisol of the humid forest zone in West Africa. Commum. Soil Sci. Plant Anal. 28:711-716

Singh, C. P., \& Amberger, A. (1990). Solubilization and availability during decomposition of rock enriched straw and urine. Biol. Agric. Hort. 7:261-269.

Truong, B., Pichot, J., \& Beunard, P. (1978). Caractérisation et comparaison des phosphates naturels tricalciques d'Afrique de l'Ouest en vue de leur utilisation directe en agriculture. Agron. Trop., 33: 136-145.

USDA, (1999). Soil Survey Staff. "Soil taxonomy: a basic system of soil classification for making and interpreting soil surveys". Agricultural Handbook No. 436. $2^{\text {nd }}$ edition. U. S. Government Printing Office, Washington, DC.

USDA, (2003). Keys to Soil Taxonomy. Soil Survey Staff. $9^{\text {th }}$ Edition. U. S. Government Printing Office, Washington, DC.

Vanlauwe, B., Diels, J., Lyasse , O., Aihou, K., Iwuafor, E.N.O., Saginga, N., Merckx, R., \& Deckers, J., (2002).Fertility status of soils of derived savanna and northern guinea savanna and response to major plant nutrients, as influenced by soil type and land use management. Nutrient Cycling in Agroecosystems 62, 139-150

Vanlauwe, B., Nwoke, O. C., Diels, J., Saginga, N., Merckx, R., Deckers, J., \& Carsky, R. J. (2000). Utilization of rock phosphate by crops on a representative sequence in northern guinea savanna zone of Nigeria: response by Mucuna pruriens, Lablab purpureus and Maize. Soil Bio. Bioch ., 32:2063-2077

Wakley, A. \& I. A. Black. (1934). An examination of the Degtjareff method for determination soil organic matter, and a proposed modificator of the Chromic acid titration method. Soil Sci. 37: 29-38

Wild, A. (1995). Soil and environment. An Introduction. Cambridge University Press. Pp. 286.

World Bank, (1992). Africa Region Sector Study: Rock Phosphate as a Capital Investment. World Bank, Washington, DC.

Zapata, F., Axmann, H., \& Braun, H. (1986). Agronomic evaluation of rock phosphate materials by means of radioisotope techniques. In ISSS \& BG, eds. Trans. 13th Int. Cong. Soil Sci., Vol. III: 1012-1013. Hamburg, Germany. 